\title{
5. CARBONATE VEINS FROM THE DÉCOLLEMENT ZONE AT THE TOE OF THE NORTHERN BARBADOS ACCRETIONARY PRISM: MICROSTRUCTURE, MINERALOGY, GEOCHEMISTRY, AND RELATIONS WITH PRISM STRUCTURES AND FLUID REGIME ${ }^{1}$
}

\author{
P. Labaume, ${ }^{2}$ M. Kastner, ${ }^{3}$ A. Trave, ${ }^{4}$ and P. Henry ${ }^{5}$
}

\begin{abstract}
Carbonate veins occur in and above the décollement zone at the toe of the northern Barbados accretionary prism, most of them spatially associated with fault zones. Four vein types were identified on the basis of their structural relations with the clayey host-sediment and their internal microstructures. In all veins, the carbonate consists mostly of rhodochrosite plus Mgkutnohorite, in spheroidal crystals that did not precipitate in open fractures as classical veins, but grew as a cement within a millimeter-thick band of sediment along the fractures. This distinctive growth feature was probably caused by the high porosity of the clayey host-sediment. In one vein type, the sediment cemented by the first generation of carbonate became rigid enough to fracture, and for these fractures to be held open during later episodes of vein formation. Vein microstructures indicate that vein formation corresponds to dilatancy episodes during which high pore pressure favored hydraulic fracturing and inhibited compactional shear strain in the fault zones.

In those veins featuring several generations of carbonates, the chemical ( $\mathrm{Sr}$ concentrations) and isotopic $(\mathrm{Sr}, \mathrm{C}, \mathrm{O})$ data indicate that the carbonates have precipitated from a fluid distinct from the present-day in situ pore water or from the contemporaneous seawater. This fluid was injected from a deeper and hotter arcward source; the extent of mixing between this exotic fluid and the in situ pore water decreased from the earliest to the latest carbonate generation, which corresponds to small amounts of a mixed dolomite plus Mg-kutnohorite. The difference between the latest vein fluid and the present-day pore water, which is highly overprinted by in situ diagenetic reactions with volcanic glass, suggests that a major fluid-flow episode has not occurred recently.

Both the microstructures and chemical features thus indicate that carbonate vein formation is controlled by episodic injection of overpressured fluid originating from deeper horizons along the fault zones, inhibiting compactional shear strain and causing hydrofracturing, permeability increase, and mineralization.
\end{abstract}

\section{INTRODUCTION}

Mineralized veins in tectonic settings attest the presence of fluids during past deformation episodes. They provide the most direct opportunity to assess the nature and origin of those fluids and their physical and chemical role in the deformation. The presence of mineralized veins is particularly relevant in the frontal part of an accretionary prism where fluids are abundant and play a major role in the evolution of the tectonic edifice (e.g., Moore and Vrolijk, 1992). However, few veins from these tectonic settings have been reported until now (Mascle, Moore, et al., 1988; Vrolijk and Sheppard, 1991; Shipboard Scientific Party, 1994; Sample and Kopf, 1995).

This paper focuses on the structural, petrological, mineralogical, and geochemical characteristics and significance of the carbonate veins sampled in and above the décollement zone at the toe of the northern Barbados accretionary prism during Ocean Drilling Program (ODP) Leg 156 (Sites 948 and 949, located 4 and $2 \mathrm{~km}$ arcward from the thrust front, respectively; see location map in Maltman et al., Chapter 22, this volume). The structural and petrographic studies of these veins give insights on the geometry of the fluid drainage system

${ }^{1}$ Shipley, T.H., Ogawa, Y., Blum, P., and Bahr, J.M. (Eds.), 1997. Proc. ODP, Sci. Results, 156: College Station, TX (Ocean Drilling Program).

${ }^{2}$ Laboratoire de Géophysique Interne et Tectonophysique, CNRS-Université Joseph Fourier, BP 53X, 38041 Grenoble Cedex 9, France.pierre.labaume@ obs.ujf-grenoble.fr.

${ }^{3}$ Scripps Institution of Oceanography, University of California, San Diego, La Jolla, California 92093-0212, U.S.A.

${ }^{4}$ Géofluides, Bassins, Eau, CNRS-Université Montpellier II, 34095 Montpellier Cedex 5, France.

${ }^{5}$ Laboratoire de Géologie, CNRS-Ecole Normale Superieure, 24 Rue Lhomond, 75231 Paris Cedex 5, France. in the lower part of the prism and the décollement zone, and on the relationships between drainage, tectonic stress, and fluid pressure. The mineralogical and geochemical analyses provide information on the characteristics of the fluids involved during past deformation episodes. When compared with the characteristics of the present pore water sampled from the same structural interval, these analyses provide a unique opportunity to follow the history of the evolving fluid during the recent accretion of the prism. Another significant aspect of this study is that the veins have formed in a weak, uncemented, and highly porous sediment, thus giving insight into the conditions in which a sediment undergoing progressive lithification may acquire a brittle behavior.

The frequency of occurrence of carbonate veins recovered at ODP Sites 948 and 949 indicates that they are more common features in the toe of the Barbados accretionary prism than suggested by previous drilling at neighboring sites (Sites 671, 675, and 676 of ODP Leg 110; Mascle, Moore, et al., 1988; Vrolijk and Sheppard, 1991), which emphasizes their importance in unraveling the fluid history in this part of the prism.

\section{METHODS}

All the mineralized veins observed in cores were carefully recorded to map their distribution and spatial relationships with lithology and other structural features (Fig. 1; Shipley, Ogawa, Blum, et al., 1995).

Eleven carbonate veins with their clayey-sediment matrix were sampled from cores from Holes 948C and 949D. Hole 948D was not cored, but five, 2- to 5-cm-long fragments of indurated vein carbonates without sediment matrix were recovered, caught in the drill-bit 
underreamer, from the lowermost part of the accretionary prism. On shore, the samples were air dried and impregnated with epoxy resin. Uncovered polished thin-sections were prepared from the impregnated samples for microstructural and petrographic studies under the optical microscope, the cathodoluminescence microscope, and the scanning electron microscope (SEM). The latter was used in backscattered electron mode and coupled with an X-ray microanalysis system (Energy Dispersive Spectrometry, EDS), allowing qualitative assessment of the chemical element content of the different mineral phases.

The five fragments of indurated vein carbonates from Hole 948D, in which distinct vein-fill generations could be identified, were emphasized to determine the degree of mineralogical and geochemical homogeneity. In three of these fragments, enough material was separated with a microdrill from the distinct vein-fill generations under a binocular microscope. Carbonate mineralogy and geochemistry of these powders were determined at Scripps Institution of Oceanography (SIO).

Mineralogy was determined by high resolution X-ray diffraction (XRD) analysis performed with a Scintag XDS 2000 instrument. Results were controlled by semi-quantitative SEM-EDS analyses of the same powders.

Oxygen, carbon, and strontium isotopic compositions were determined by mass spectrometry. The stable isotopes of oxygen and carbon of the carbonate phases were analyzed following the method of McCrea (1950). The precision was $0.04 \%$ o for oxygen and $0.03 \%$ o for carbon. The isotopic results are reported in the conventional fashion as $\delta^{18} \mathrm{O}$ and $\delta^{13} \mathrm{C}$ in per million relative to Peedee belemnite (PDB). The carbonate samples were dissolved in $1.8 \mathrm{~N}$ ultra-clean $\mathrm{HCl}$ for strontium isotope ratios and concentration analyses. Strontium isotope ratios were determined using standard mass spectrometric techniques. The $2 \sigma$ errors are given with results. All measured ${ }^{87} \mathrm{Sr} /{ }^{86} \mathrm{Sr}$ ratios were normalized to a particular value $\left({ }^{86} \mathrm{Sr} /{ }^{88} \mathrm{Sr}\right)$ for a standard; the value obtained for the National Bureau of Standards (NBS) 987 standard measured in the SIO laboratory is 0.710255 , with a $2 \sigma$ error of 16 . The $\mathrm{Sr}$ concentrations were also determined by mass spectrometry, using isotope dilution.

Quantitative chemical element analyses were performed on thin sections made from the five vein fragments from Hole 948D, using an electron microprobe CAMECA model SX-50, at Barcelona University, Spain. $\mathrm{Ca}, \mathrm{Mg}, \mathrm{Mn}, \mathrm{Fe}, \mathrm{Sr}, \mathrm{Ba}$, and $\mathrm{Na}$ were analyzed. The operating conditions were $20 \mathrm{kV}$ excitation potential, $15 \mathrm{nA}$ current intensity, and $10 \mu \mathrm{m}$ of beam diameter. The standards used were calcite $(\mathrm{Ca})$, periclase $(\mathrm{Mg})$, rhodonite $(\mathrm{Mn})$, garnet $(\mathrm{Fe})$, celestite $(\mathrm{Sr})$, barite $(\mathrm{Ba})$, and albite $(\mathrm{Na})$. $\mathrm{C}$ and $\mathrm{O}$ were calculated assuming all the elements were in carbonates. Results were calculated in weight percent of carbonates. Only the analyses summing at $100 \% \pm 2 \%$ were taken into account, then converted to mole percent of carbonates. In all analyses, the major elements are $\mathrm{Ca}, \mathrm{Mg}$, and $\mathrm{Mn}$, whereas $\mathrm{Fe}, \mathrm{Sr}$, $\mathrm{Ba}$, and $\mathrm{Na}$ have very low concentrations $(<1 \%$, often below the detection limit). The values obtained for these minor elements are not considered as meaningful, and therefore only the values of the three major elements are reported in this paper. The standard deviation was 0.38 for $\mathrm{Mg}, 0.90$ for $\mathrm{Ca}$, and 0.91 for $\mathrm{Mn}$.

\section{OCCURRENCE, MICROSTRUCTURE, AND PETROLOGY OF CARBONATE VEINS}

The distribution of the carbonate veins found in cores from Holes 948C and 949B is summarized in Figure 1. In both holes, carbonate veins occur only in the smectitic claystones constituting the lower part of the prism and upper part of the décollement (lithologic Unit II; Shipley, Ogawa, Blum, et al., 1995), whereas they are absent in the claystone and chalk turbidite section that constitutes the lower part of the décollement and underthrust section (lithologic Unit III).

The veins from Hole 948D were recovered without their sediment matrix. Although their precise depth interval is unknown, based on the underreaming operations they originate from about $480 \mathrm{~m}$ below seafloor (mbsf; G. Foss, pers. comm., 1994), which corresponds to the lowermost $10 \mathrm{~m}$ of the accreted prism at nearby Hole 948C (Fig. 1). By analogy with the cored holes, we thus conclude that these veins originate from lithologic Unit II. These non-curated samples are referred to as "Sample 156-948D-no.x" $(x=1-5)$.

All of the carbonate veins sampled during Leg 156 can be classified into four types (Fig. 2). Type 1, 2, and 3 veins occur in the sediments of Holes 948C and 949B, and are differentiated on the basis of their morphology and their mode of structural association with the host-sediment. The veins from Hole 948D constitute the fourth type. They display the greatest variety of microstructures found in the veins sampled during Leg 156. Therefore, most of the petrographic, mineralogical, and geochemical analyses reported in the present paper were performed on these particular samples.

\section{Type 1 Carbonate Veins}

\section{Occurrence and macroscopic characteristics}

Type 1 carbonate veins occur within the scaly-fabric zones in the clayey sediment (Figs. 2, 3). These centimeter-thick zones are the horizons where shear deformation and tectonic displacement are concentrated (Labaume et al., Chapter 4, this volume). The scaly-fabric zones are concentrated in meter- to tens-of-meters-thick intervals corresponding to the fault zones in the prism and the décollement zone (Fig. 1; Maltman et al., Chapter 22, this volume). In Hole 948C, Type 1 veins occur mostly in the fault zones in the lower part of the prism (Sections 156-948C-2X-2, 2X-5, and 7X-3; CV1 in Fig. 1); only one vein is present in a shear zone within the décollement (Section 156-948C-10X-5). In Hole 949B, only one Type 1 vein was found, in a shear zone in the lower part of the prism (Section 156949C-5X-4).

Type 1 veins dip parallel to the scaly foliation (Fig. 3) or, more rarely, are subhorizontal along the shear-zone boundaries or internal shear surfaces. In the first case, they form sets of parallel veins separated by a few millimeters. These veins are less than $1 \mathrm{~mm}$ thick, and up to several centimeters long. In general, they appear massive and have sharp boundaries with no evidence of striation. In a few cases, the vein consists of a group of aligned but disconnected spheroidal crystals up to $1 \mathrm{~mm}$ in diameter. The vein-fills are white to pink in color.

\section{Microscopic observations}

The most common occurrence of Type 1 veins observed in thin sections exhibits vein sets parallel to the scaly foliation, specifically along the "spaced foliation" defined by Labaume et al. (Chapter 4, this volume) (Fig. 4A). The vein-set geometry corresponds to the geometry of the spaced foliation: most of the veins are subparallel to each other, but a few of them are bifurcated in an anastomosed pattern. The vein walls are rectilinear to irregular (Fig. 4B).

Under the optical microscope, the vein-fill generally appears as a microsparite made of crystals 5-40 $\mu \mathrm{m}$ across (Figs. 2, 4C). The crystals are poorly connected and separated by clayey host-sediment. Locally, the vein-fill is a gray micrite. The larger crystals in the microsparite are often along the vein walls, and crystals of different sizes may form parallel bands, but zoning of crystal sizes is not systematic.

The samples also contain larger, up to $0.1 \mathrm{~mm}$ in diameter, single spheroidal crystals with a radial fibrous texture in the host-sediment, and more rarely in the vein-fill (Fig. 4C).

The veins are frequently deformed by folding, brittle rupture, pulling-apart, or disaggregation along shear surfaces, but it is difficult to differentiate natural from drilling-induced deformation (see discussion in Labaume et al., Chapter 4, this volume). However, intervals between pulled-apart vein fragments that are filled with mas- 


\begin{tabular}{|cl|}
\hline CV1, 2, 3 & Type 1, 2, and 3 carbonate veins, \\
ZV & respectively \\
SV & Zeolite-smectite vein \\
B & Sediment-filled vein \\
Z & Minociated zone \\
$\geqslant$ & Minor reverse fault \\
$\mathbb{V}$ & Minor normal fault \\
$\infty$ & Stratal disruption \\
\hline
\end{tabular}

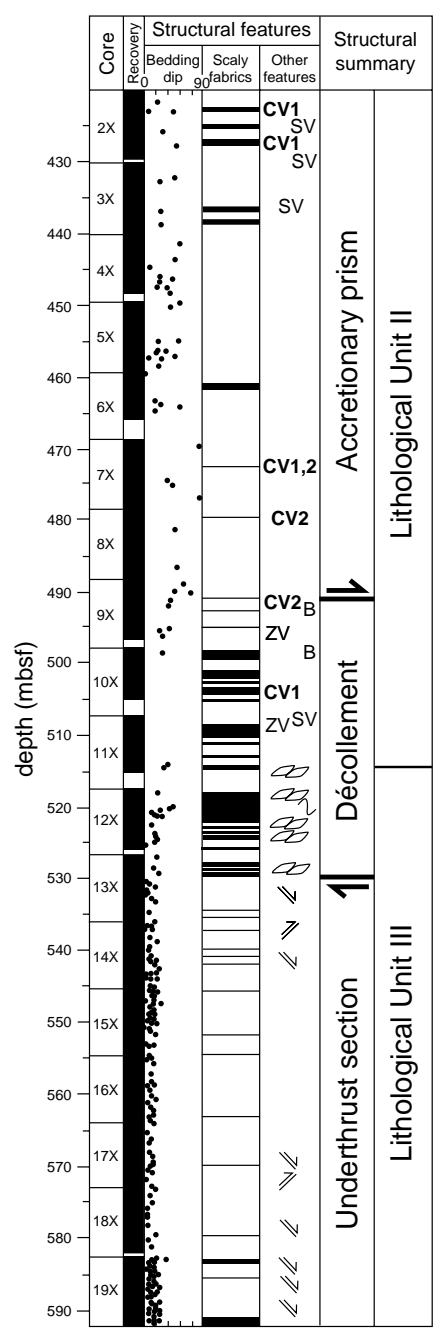

Hole $948 \mathrm{C}$

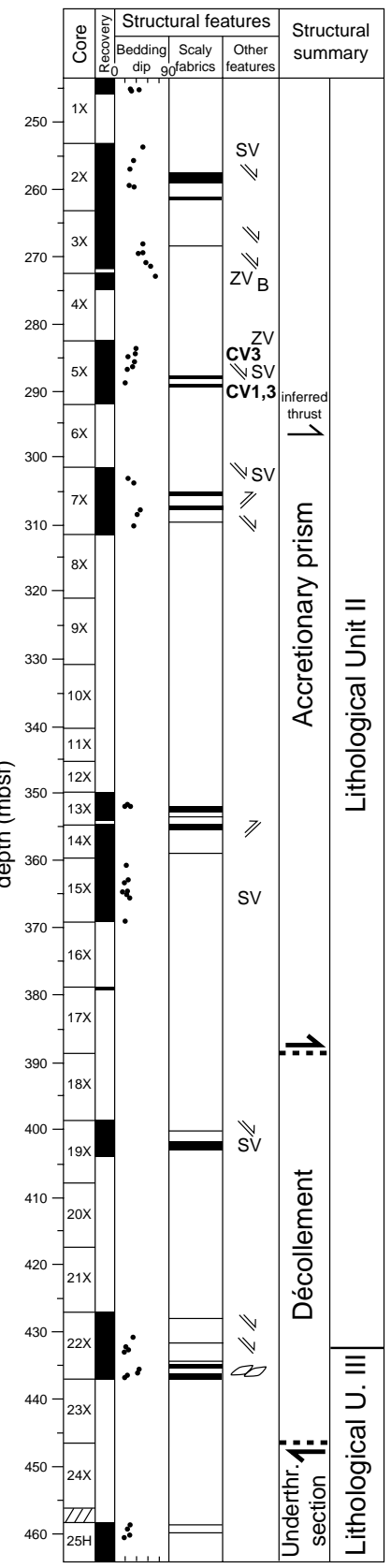

Hole 949B
Figure 1. Structural columns of Holes $948 \mathrm{C}$ and $949 \mathrm{~B}$, showing the distribution of carbonate veins in the cored intervals. Holes 948C and 949B are located 4 and $2 \mathrm{~km}$ arcward from the deformation front, respectively (location map in Maltman et al., Chapter 22, this volume).

sive, clayey host-sediment suggest natural deformation at least in these particular cases.

The backscattered SEM images show that carbonate crystals are formed by very small $(<5 \mu \mathrm{m})$ rhombohedra that occur either isolated in the clayey host-sediment or grouped in spheroidal crystals up to 40 $\mu \mathrm{m}$ in diameter (Figs. 4D-4F); the rhombohedra are poorly connected at the spheroid periphery. The smallest spheroids are dispersed in abundant clayey host-sediment (Fig. 4E). As the spheroids become bigger, they are more closely spaced, eventually connected, and the size of the clayey inclusions is reduced (Fig. 4F). In those spheroids
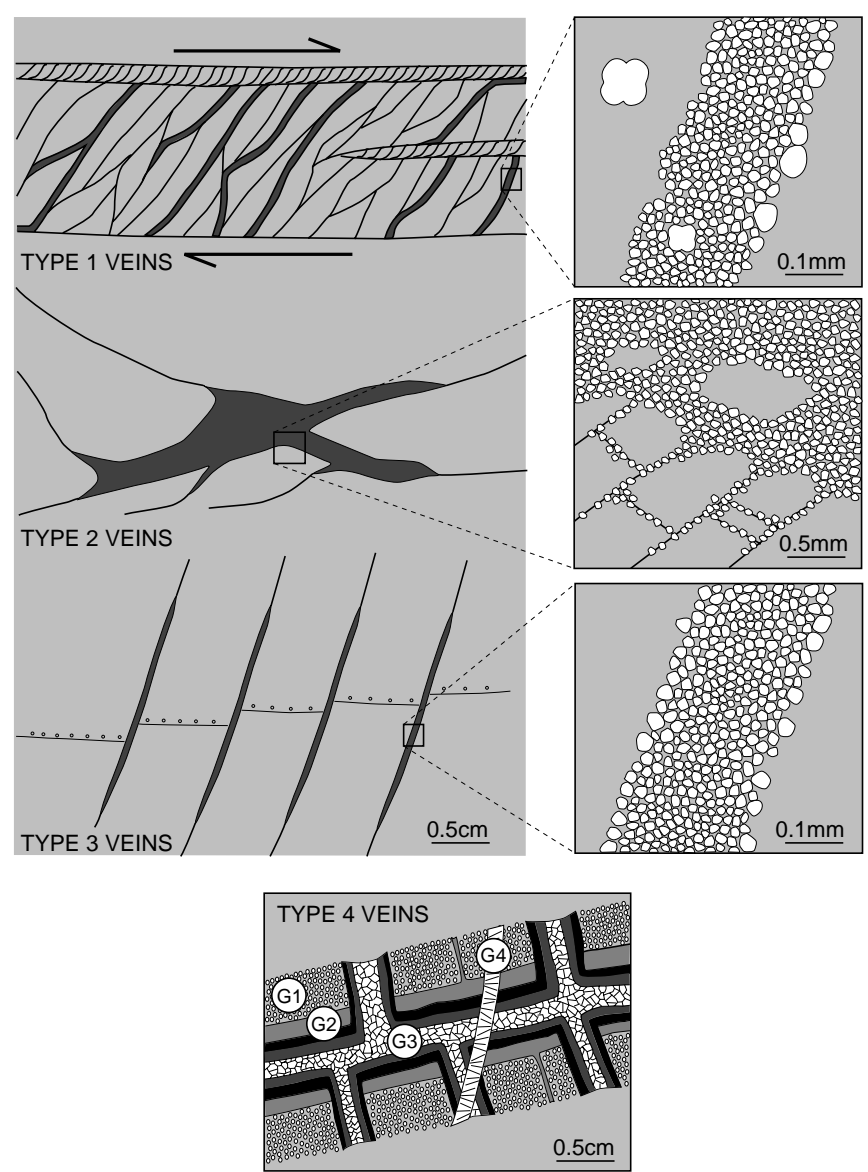

Figure 2. Summary of main structural and textural features of the four carbonate vein types defined in this paper. Light gray = clayey host-sediment, medium gray, black and white $=$ vein carbonates. Type 1 veins parallel the foliation in scaly-fabric zones (shear zones; see Labaume et al., Chapter 4, this volume), Type 2 veins are irregular crystal patches along fractures close to shear zones, and Type 3 veins parallel sharp fractures or microfaults. Type 4 veins were sampled without their clayey matrix and contain several generations of carbonate (G1, G2, G3, and G4), with G2 and G3 featuring multiple successive episodes of precipitation (the vein external geometry is hypothetical). Vein-fills in Types 1 to 3 veins and G1 in Type 4 veins consist of agglomerates of poorly connected spheroidal crystals and contain abundant clayey inclusions; G2 and the early stages of G3 consist mainly of micrite, and the late stages of G3 and G4 consist of microsparite, sometimes fibrous in the case of G4 (crystal size in G1 and the late microsparite in G3 is exaggerated).

having a radial fibrous texture, clayey host-sediment is intercalated between the fibers in the external part of the spheroid.

\section{Type 2 Carbonate Veins}

\section{Occurrence and macroscopic characteristics}

Type 2 carbonate veins occur across massive sediment affected by millimeter- to centimeter-spaced fractures (Figs. 2, 5). They are present only in Hole 948C, in the lower part of the prism (Sections 156-948C-7X-3, 8X-2) and at the top of the décollement zone (Section 156-948C-9X-3; Fig. 1). The veins of this type are located a few centimeters to decimeters away from scaly-fabric zones (i.e., they are spatially associated with the fault zones).

Type 2 veins are a few millimeters to $1 \mathrm{~cm}$ thick and show irregular geometries, bifurcations, and variable dips (Fig. 5). Vein-fill 


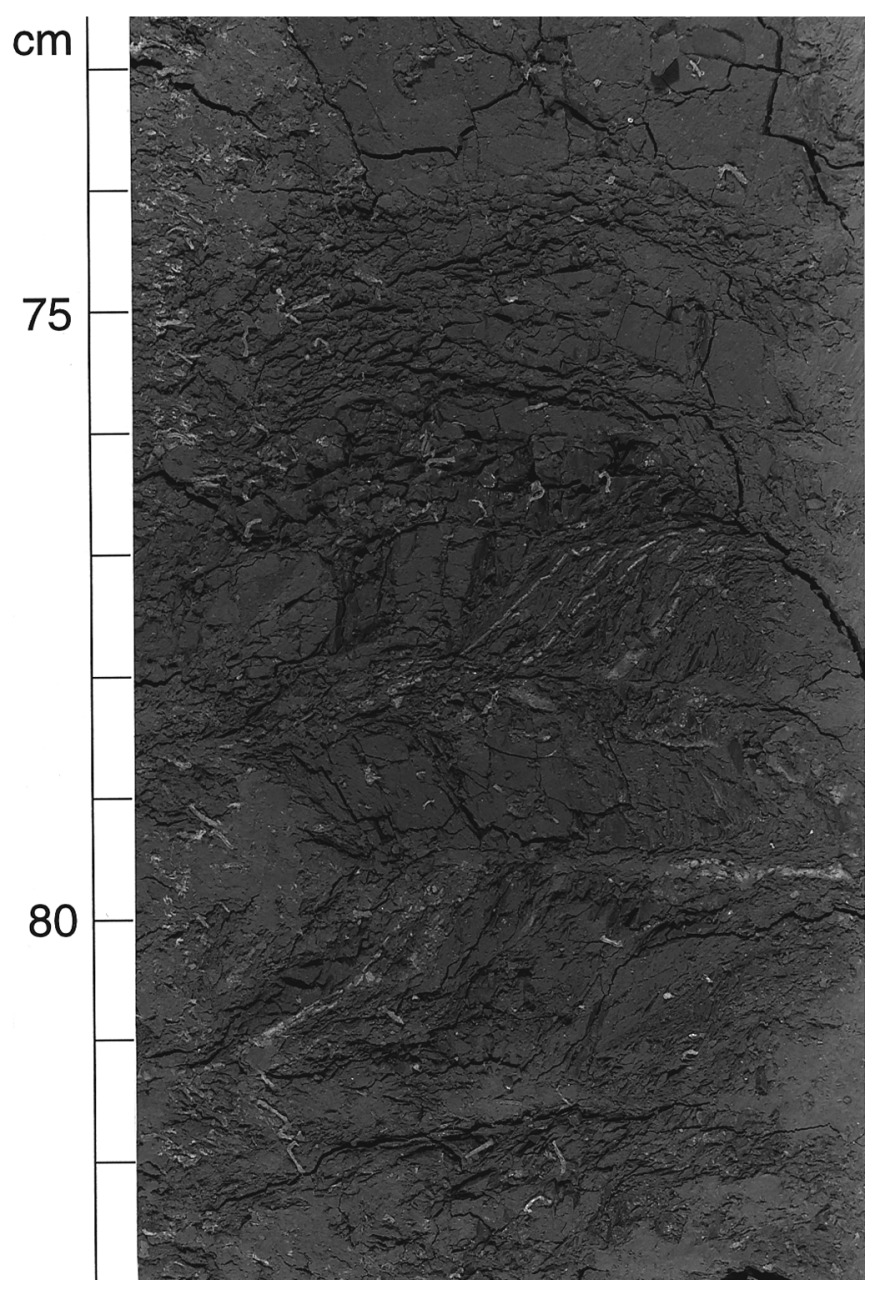

Figure 3. Type 1 carbonate veins, macroscopic characteristics (Sample 156$948 \mathrm{C}-2 \mathrm{X}-5,73-83 \mathrm{~cm})$. The veins appear as thin white stripes along steeply dipping scaly foliation. Horizontal upper boundary of the scaly-fabric zone and adjacent undeformed sediment appear in the upper part of the picture. The core was disrupted along horizontal surfaces and core pieces ("biscuits") rotated around core axis, as indicated by changes of dip direction of the foliation.

consists of agglomerates of poorly connected spheroidal pink crystals up to $1 \mathrm{~mm}$ in diameter. Vein boundaries are diffuse, due to the intercalation of clayey host-sediment between the carbonate crystals. The host-sediment may have a greenish alteration halo around the vein.

\section{Microscopic observations}

Under the optical microscope, Type 2 veins consist of carbonate crystals that are grouped in irregular patches or occur isolated across massive, clayey host-sediment (Figs. 2, 6A). The vein-fill is generally a microsparite made of crystals up to $50 \mu \mathrm{m}$ in diameter, separated by dark gray material in the patches. The largest crystals are spheroidal and show a radial fibrous texture. Locally, the vein-fill is a gray micrite. There is no systematic zoning of the crystal sizes in these veins.

The large carbonate patches contain millimeter-size inclusions of clayey sediment (CI in Fig. 6B). The small patches and isolated crystals are generally aligned to form millimeter-scale networks of discontinuous microveins of different directions (VN in Fig. 6B).

The backscattered SEM images show that the crystals are spheroids made of very small $(<5 \mu \mathrm{m})$ rhombohedra, poorly connected at the spheroid periphery (Fig. 6D). In the crystal patches, the spheroids are poorly connected, and spaces between them are filled with clayey host-sediment, which corresponds to the dark gray material observed between the carbonate crystals under the optical microscope.

\section{Type 3 Carbonate Veins}

\section{Occurrence and macroscopic characteristics}

Type 3 carbonate veins occur along sharp fractures in macroscopically undeformed sediment (Figs. 2, 7). All veins of this type have been found in Hole 949B and are concentrated in a 7.8-m-thick interval in the lower part of the prism (Sections 156-948C-5X-2 through 5X-CC; Fig. 1). The Type 3 veins are abundant in this interval and are spatially associated with the greatest concentration of sedimentfilled veins found in cores from Leg 156 (Maltman et al., Chapter 22, this volume). At the core scale, the relation of Type 3 veins with scaly-fabric zones is less obvious than in the case of Type 1 and 2 veins. However, two, centimeter-thick scaly-fabric zones, one of them with small Type 1 veins, are present in the same interval, and the veined interval is located a few meters above an inferred major thrust fault (Fig. 1).

Most of the veins are steeply dipping (Fig. 7), with only one subhorizontal vein. They have sharp bounding faces that may show dipslip striations. The striations suggest that the fractures correspond to microfaults, which is confirmed in a few cases by a few millimeterwide normal offsets of the bedding. Vein-fill is pink in color.

\section{Microscopic observations}

Type 3 veins have been observed only under the optical microscope. They show rectilinear to irregular boundaries and a microsparitic fill made of crystals up to $50 \mu \mathrm{m}$ across (Figs. 2, 8A). Crystals of different size may form stripes parallel to the vein trend. In this case, the smallest crystals generally occur at the vein center, whereas the largest crystals occur at the vein edges. The crystals are poorly connected and separated by clayey host-sediment (Fig. 8B). These characteristics are very similar to those of Type 1 veins.

\section{Type 4 Carbonate Veins}

\section{Occurrence and macroscopic characteristics}

Type 4 carbonate veins correspond to the five vein samples recovered (probably) immediately above the décollement zone at Hole 948D; their exact depth and mode of structural association with the host-sediment are unknown.

The samples consist of about 2 - to 5 -cm-long $(4.5 \times 3.5 \times 2 \mathrm{~cm}$ for the largest one) vein fragments of irregular shapes. All samples have similar microstructural, petrographic, mineralogic, and geochemical characteristics, suggesting that they are either fragments from a large single vein, or represent a cluster of neighboring, genetically related veins. This implies that this vein or cluster of veins is an order of magnitude larger than the largest veins observed in the cores from Holes 948C and 949B.

Each sample features polygonal, more or less rectangular domains of gray material separated by pink, locally milky-white, material. The gray material is mostly made of submillimeter crystals and contains numerous millimeter-size inclusions of the clayey host-sediment. The pink material appears massive, with complex pink-shaded zonation in stripes parallel to the boundaries between the gray and pink domains. The milky-white material forms thin stripes intercalated between the pink stripes.

\section{Microscopic observations}

Under the optical microscope, vein-fill textures and cross-cutting relationships show that the gray material was the first formed and comprises two successive vein-fill generations (G1 and G2 in Figs. 2 and 9), whereas the pink and milky-white material corresponds to a third generation cross-cutting the previous ones (G3 in Figs. 2 and 9). 

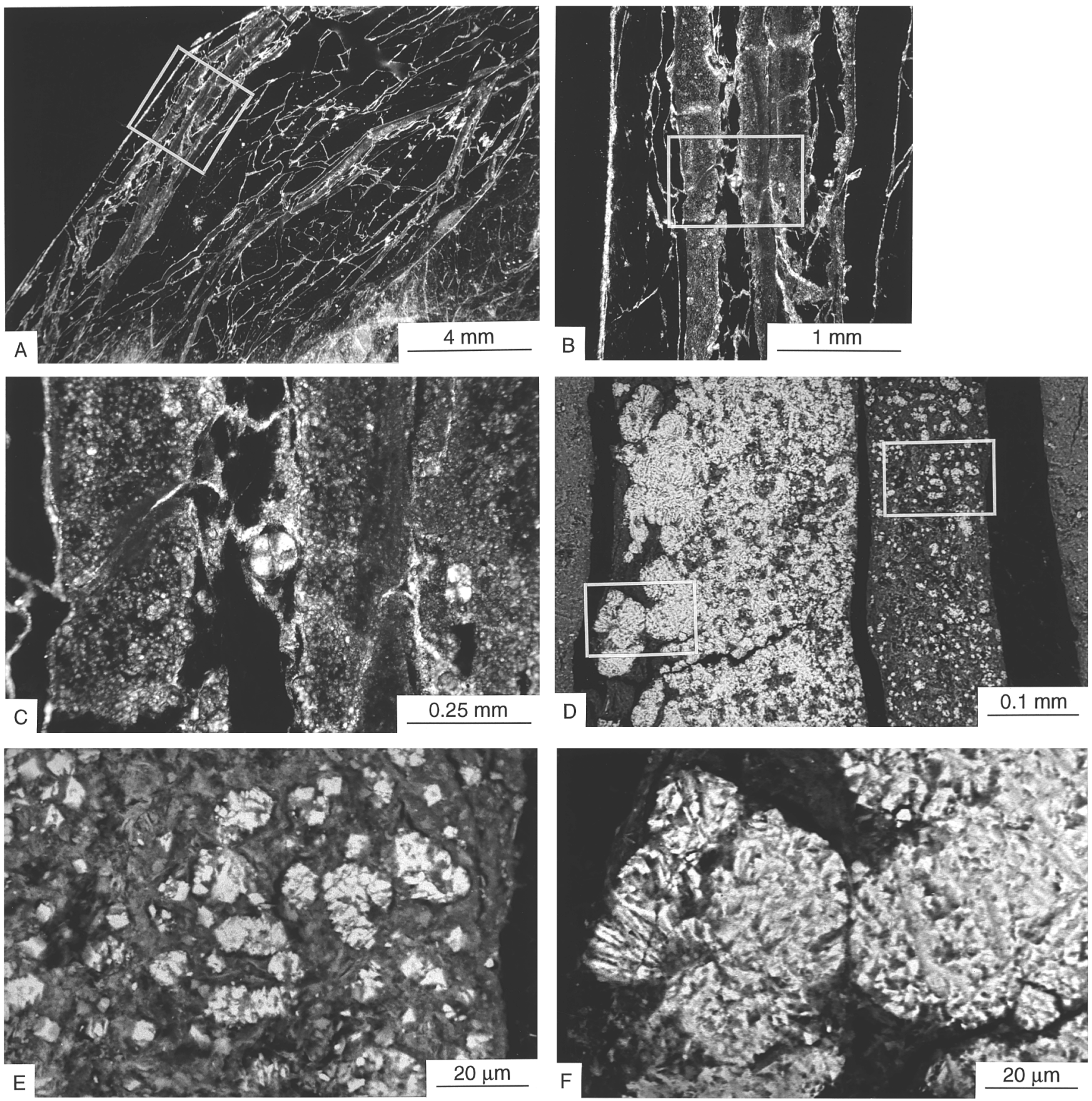

Figure 4. Type 1 carbonate veins, microscopic characteristics. A. Micrograph showing Type 1 vein general geometry. The veins occur along the scaly foliation (left-dipping fractures, some of them opened during sample air-drying; Sample 156-948C-2X-5, 81-83 cm). Frame = location of B. B. Detail of A. Veins have either sharp or irregular walls. Frame $=$ location of $\mathbf{C}$. C. Detail of $\mathbf{B}$. Carbonate vein-fill is a microsparite with bands of varying grain sizes parallel to the vein walls and inclusions of clayey host-sediment. Large spheroidal crystals with radial fibrous texture occur either inside (right) or outside (center) the veins. D. Backscattered SEM image of vein-fill. Carbonate crystals (white) are small and dispersed in clayey host-sediment (gray) in the right part of the vein, and become larger and partly connected with clay intercalations toward the left (black = fractures opened during sample air-drying; Sample 156-948C-2X-5, 78-81 $\mathrm{cm}$ ). Frames = locations of $\mathbf{E}$ (right) and $\mathbf{F}$ (left). E. Detail of $\mathbf{D}$ (right part). Carbonate crystals are rhombohedra isolated or agglomerated in small spheroids. $\mathbf{F}$. Detail of $\mathbf{D}$ (left part). Carbonate crystals are large spheroids formed of agglomerated rhombohedra, some of them with a fibrous texture (left).

Three samples also contain one or two thin (width $<1 \mathrm{~mm}$ ) vein(s) of a fourth generation, which cross-cuts the three previous ones (G4 in Figs. 2 and 9).

\section{Generation 1 Vein-fill (G1)}

Under the optical microscope, G1 appears as a microsparite made of subequant yellowish carbonate crystals $\sim 20-30 \mu \mathrm{m}$ across, separat- ed by dark gray material (Fig. 10A). G1 contains up to millimetersize inclusions of clayey sediment (CI in Fig. 10A). Around these inclusions, the carbonate crystals are larger $(\sim 50 \mu \mathrm{m})$ and lighter in color than the rest of the crystals, and frequently show a palisade geometry, with a flat surface on the inclusion side. Along the boundaries with G2 there is a row of crystals slightly larger and lighter in color than the other crystals (Fig. 11A). 


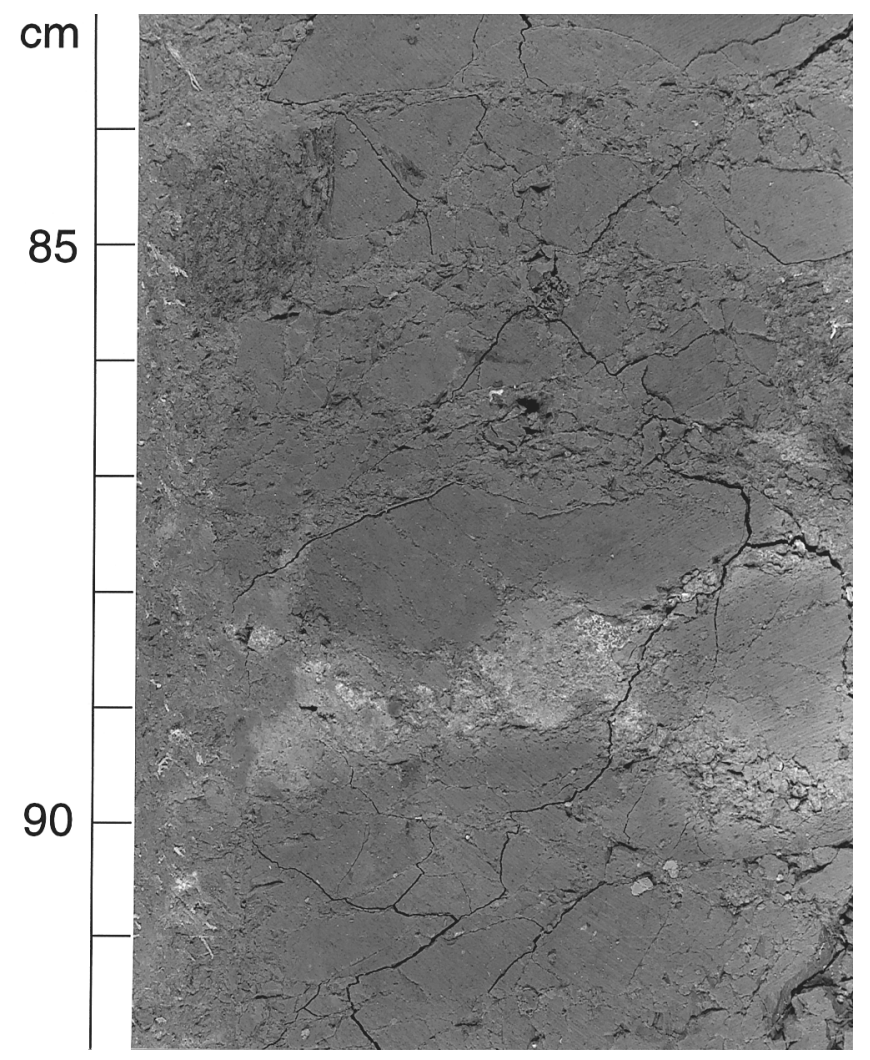

Figure 5. Type 2 carbonate veins, macroscopic characteristics (Sample 156948C-7X-3, 83-92 cm). The subhorizontal vein has an irregular shape and occurs across weakly fractured sediment.

The backscattered SEM images show that G1 carbonate crystals are spheroids that consist of a great number of very small $(\leq 5 \mu \mathrm{m})$ rhombohedra (Fig. 10B). The spheroids, as well as the rhombohedra within the spheroids, are poorly connected. The spheroids are separated by clayey host-sediment comprising clay, feldspar, quartz, zircon, and Fe and Ti oxide grains, as determined by EDS analyses. This sediment corresponds to the dark gray material observed between the carbonate crystals under the optical microscope, and has the same composition as that of the smectitic lithologic Unit II, determined by shipboard XRD analyses (Shipley, Ogawa, Blum, et al., 1995). Single feldspar, quartz, zircon, and oxide grains may form inclusions in the spheroids. Under the cathodoluminescence microscope, G1 carbonate is non-luminescent.

\section{Generation 2 Vein-fill (G2)}

The boundaries between G1 and G2 have an irregular geometry at the submillimeter scale, but at the centimeter scale they are rectilinear and trend in a single direction across the samples, except rare very thin G2 veinlets across G1 that are subperpendicular to this major trend (Fig. 9).

Under the optical microscope, G2 consists of gray micrite, with local domains of translucent microsparite made of carbonate crystals up to $20 \mu \mathrm{m}$ across (Fig. 11A). In the micrite, domains with different degrees of gray shades are arranged either in irregular patches, or in undulated bands roughly parallel to the boundaries between G1 and G2. The microsparite forms bands parallel to the micrite bands and shows progressive increase in crystal size from the micrite toward the coarsest microsparite. Millimeter-size clayey inclusions are present only in the micrite and are surrounded by a row of yellowish crystals a few tens of microns across.

The backscattered SEM images show that the density of the gray shades observed under the optical microscope in the micrite is related to crystal size: the optically darkest micrite corresponds to crystals $\leq 5$ $\mu \mathrm{m}$, and the micrite crystals become progressively larger in the optically lighter micrite (Fig. 11B), up to the microsparite size. Voids between the crystals are frequent and bounded by euhedral crystal surfaces. In the micrite, the inclusions of clay, quartz, feldspar, and $\mathrm{Fe}$ and $\mathrm{Ti}$ oxide grains become rarer with increasing grain size, and eventually disappear in the microsparite. Locally, the microsparite contains abundant inclusions of barite crystals, most of them prismatic, up to $0.1 \mathrm{~mm}$ long (Fig. 11C). Under the cathodoluminescence microscope, G2 carbonate is non-luminescent.

\section{Generation 3 Vein-fill (G3)}

G3 occurs in bands with two subperpendicular directions (Fig. 9). One of these directions is parallel to that of the boundaries between G1 and G2, the G3 bands being then bounded by G2 on each side. The G3 bands in the other direction cross-cut both the G1 and G2 domains. The boundaries between G3 and the previous generations are more regular in shape than those between $\mathrm{G} 1$ and $\mathrm{G} 2$.

Under the optical microscope, G3 varies from a black micrite to a translucent microsparite made of crystals up to $30 \mu \mathrm{m}$ across, intermediate textures corresponding to a more or less dark micrite (Figs. 12A, 12B). The milky-white material observed on the hand samples corresponds to the largest microsparite domains. The different textures form very complex patterns, in general consisting of parallel bands or breccia-like structures (Fig. 12A). The bands are roughly parallel to the boundaries between G3 and the previous generations, and make right angles where these boundaries change from parallel to subperpendicular to the trend of G2 (Figs. 9, 12A). Cross-cutting relationships show that these patterns in G3 result from numerous successive stages of multidirectional rupture and crystallization. The darkest material generally formed first and the microsparite last, successive vein-fills having an increasingly lighter color with time.

The backscattered SEM images show that the different textures observed under the optical microscope in G3 correspond to variable size of the carbonate crystals: the optically black micrite corresponds to crystals $\leq 5 \mu \mathrm{m}$ (Fig. 12C), and the crystals become larger and larger as the micrite becomes optically lighter and grades into the microsparite (Fig. 12D). Voids between crystals are frequent and bounded by euhedral crystal surfaces. There are no inclusions of clayey sediment. On the other hand, barite inclusions are abundant in G3, but occur with a highly heterogeneous spatial distribution. Barite is not systematically related to particular carbonate textures, either the micrite or the microsparite domains can be the richest in barite. Barite crystals are generally disconnected from each other, and vary from $\leq 1-\mu \mathrm{m}$ subrounded crystals, to about 3 - to $8-\mu \mathrm{m}$ long prismatic and platy crystals, and to $>20-\mu \mathrm{m}$ long very irregular, etched crustlike anhedral crystals. Size of the barite crystals increases together with the size of the surrounding carbonate crystals. Locally, barite forms continuous veins across the carbonate (Figs. 12E, 12F). Under the cathodoluminescence microscope, G3 carbonate is non-luminescent.

\section{Generation 4 Vein-fill (G4)}

G4 consists of carbonate crystals that vary from rhomb-shaped to fibrous, with the long axis perpendicular to the vein walls. In one case (Fig. 13), the fibres show a pattern divergent toward the center of the vein, attesting to nucleation on the vein-walls and growth toward the vein axis (syntaxial growth; Ramsay and Huber, 1983). Under the cathodoluminescence microscope, G4 carbonate is non-luminescent.

\section{MINERALOGY OF VEIN CARBONATES}

In Type 1, 2, and 3 veins, carbonates consist of rhodochrosite, as determined by shipboard XRD analyses (Shipley, Ogawa, Blum, et al., 1995).

Based on the textural relations described above and color, three types of vein minerals clearly distinguishable at the macroscopic 

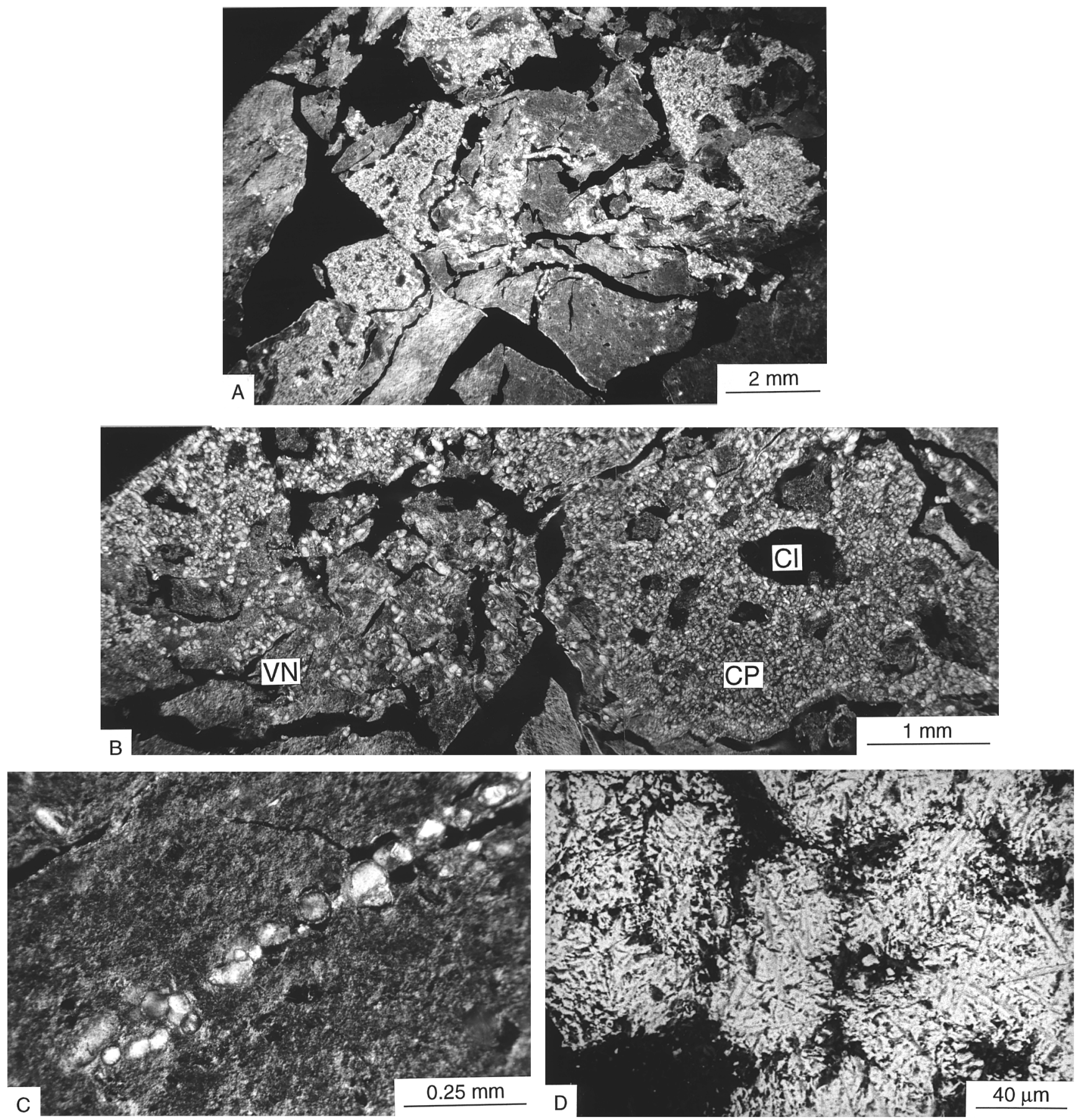

Figure 6. Type 2 carbonate veins, microscopic characteristics (Sample 156-948C-7X-3, 68-70 cm). A. Micrograph showing Type 2 vein general geometry. Veinfill forms irregular patches and microvein networks (black = fractures opened during sample air-drying). B. Micrograph showing detail of a carbonate patch (CP) with microsparite texture and millimeter-size clayey host-sediment inclusions (CI), and a discontinuous microvein network (VN). C. Micrograph showing detail of a discontinuous microvein formed by aligned, poorly connected spheroidal crystals with a radial fibrous texture. D. Backscattered SEM image of veinfill. Carbonate crystals (white) are spheroids formed of small rhombohedra. Clayey host-sediment (dark gray) is intercalated between the spheroids.

scale were separated by a microdrill from three of the five fragments of Type 4 veins for high resolution XRD analyses: G1, and the pink (micrite), and milky-white (late microsparite) materials in G3. G2 and G4 were not identified during microdrill sampling. All carbonates analyzed consist of solid solutions. $\mathrm{G} 1$ is rhodochrosite $\left(\mathrm{MnCO}_{3}\right)$ plus $\mathrm{Mg}$-kutnohorite (kutnohorite is $\mathrm{CaMn}\left(\mathrm{CO}_{3}\right)_{2}$, and in Mg-kutnohorite, $\mathrm{Mg}$ substitutes for some Mn). In G3, the micrite is Mg-kutnohorite plus rhodochrosite, and the late microsparite is dolomite $\left(\mathrm{CaMg}\left(\mathrm{CO}_{3}\right)_{2}\right)$ plus Mg-kutnohorite (Table 1). G1 is rich in feldspar, quartz, and clay-mineral inclusions. Barite is the main inclusion in the G3 micrite, and the G3 late microsparite is almost free of inclusions.

\section{CHEMISTRY OF CARBONATES IN TYPE 4 VEINS}

Carbonate major-element chemistry was determined in Type 4 veins by electron microprobe analysis of the four vein-fill genera- 


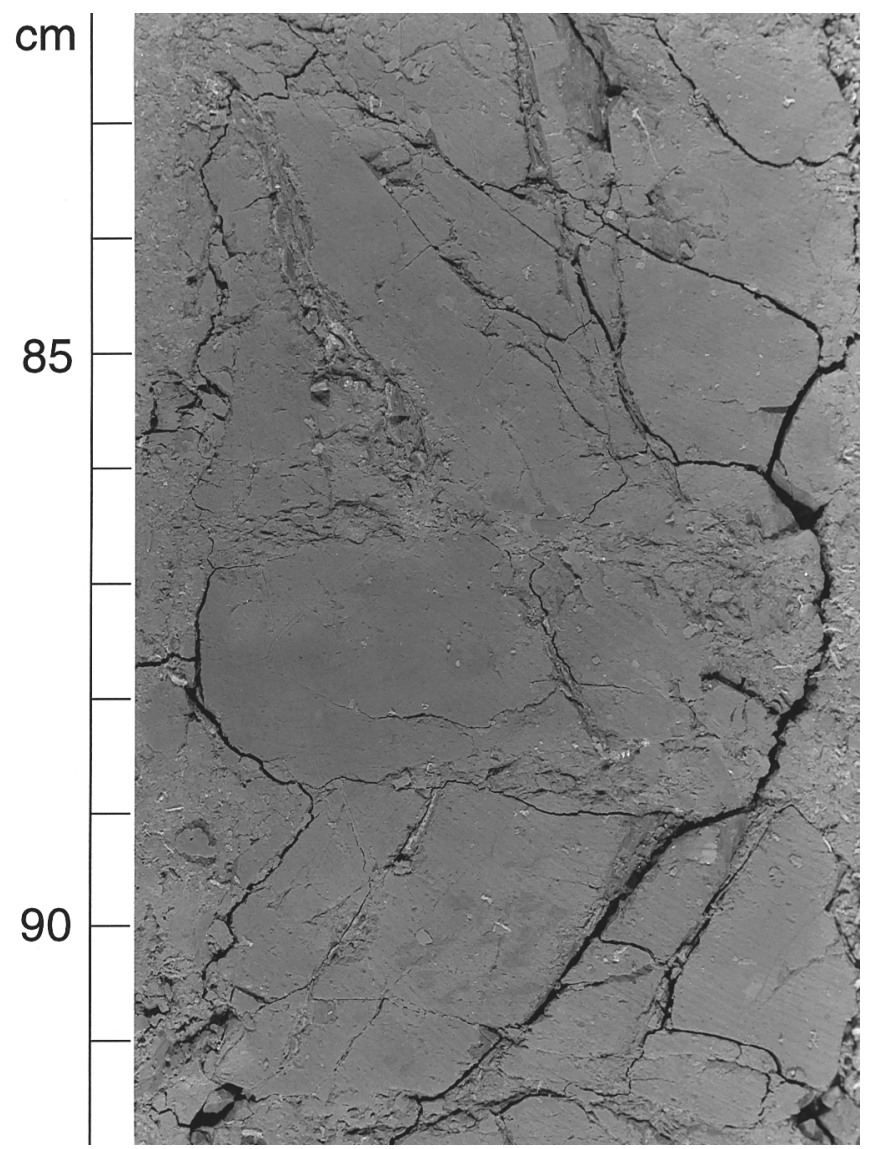

Figure 7. Type 3 carbonate veins, macroscopic characteristics (Sample 156949B-5X-3, 82-92 cm). Veins occur along steeply dipping sharp fractures across undeformed sediment. The core was disrupted along horizontal surfaces and core pieces ("biscuits") rotated around the core axis, as indicated by changes of dip direction of the veins.

tions. Analyses were performed along 15 transects in four of the samples, which corresponds to a total of 344 analysis points (Table 2). Each carbonate generation has a remarkably constant and distinct geochemistry, with the exception of (1) the values of one transect in G3 in Sample 156-948D-no.1a, and (2) the crystals surrounding the clayey host-sediment inclusions in G1 and G2, which show variable values. In Table 2, the latter crystals have been distinguished as G1' and G2', respectively. Therefore, significant mean geochemical values for the carbonate of each vein-fill generation may be calculated (Table 3).

In the three vein-fill generations, the carbonates consist of solid solutions between $\mathrm{MnCO}_{3}, \mathrm{CaCO}_{3}$, and $\mathrm{MgCO}_{3}$ (Table 3).

$\mathrm{MnCO}_{3}$ is the major component of $\mathrm{G} 1, \mathrm{G} 2$, and $\mathrm{G} 3$ carbonates. Its concentration is similar in G1 and G2, decreases slightly from G2 to $\mathrm{G} 3$, then strongly from G3 to G4. This decrease corresponds (1) to an increase in $\mathrm{CaCO}_{3}$ content, which becomes the major component in $\mathrm{G} 4$, and (2) to an increase in $\mathrm{MgCO}_{3}$ content in $\mathrm{G} 3$, but a decrease in $\mathrm{MgCO}_{3}$ content in $\mathrm{G} 4$.

In G3 carbonate, no clear variations of major-element concentrations can be correlated with the mineralogical variations revealed by the XRD analyses. Two possible explanations can be invoked.

1. Because the microprobe electron beam analyses several cubic millimeters of material, the criss-crossing of different vein-fill
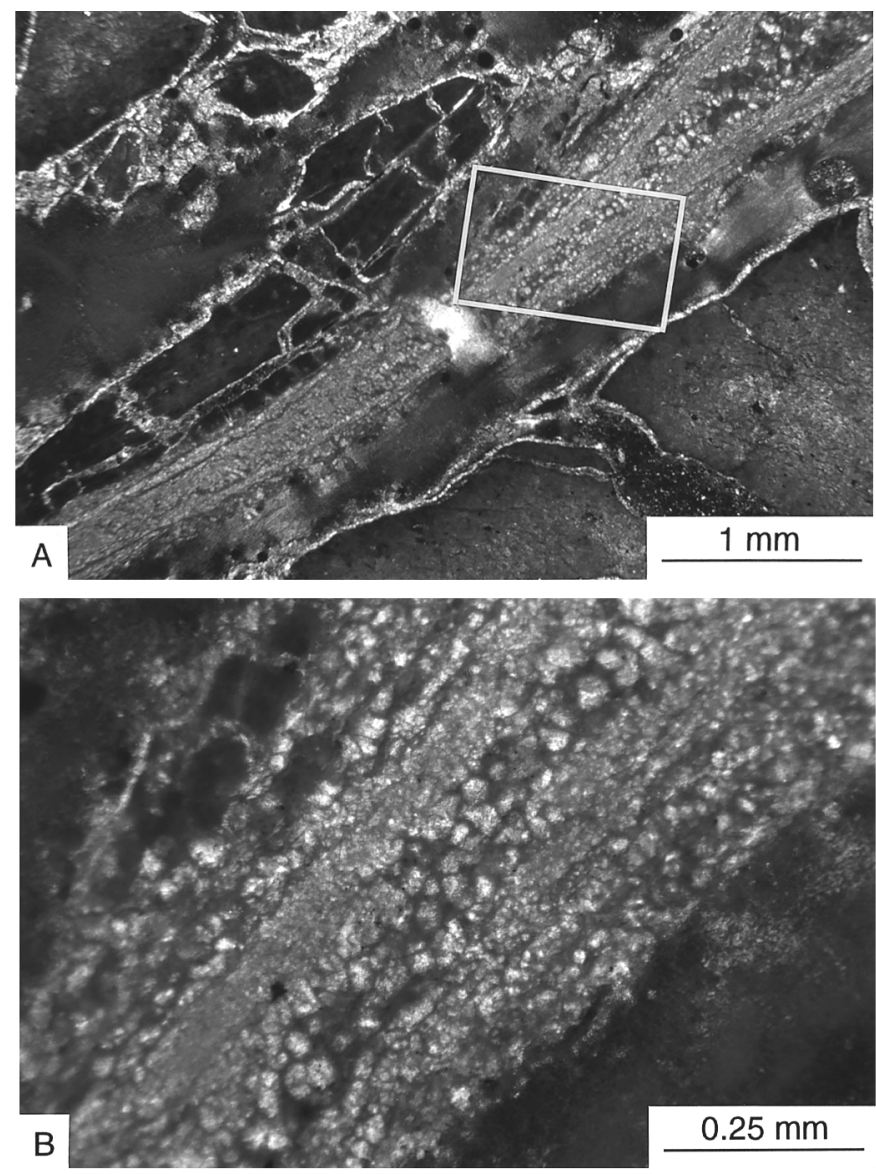

Figure 8. Type 3 carbonate veins, microscopic characteristics (Sample 156949B-5X-3, 89-93 cm). A. Micrograph showing Type 3 vein general geometry. The vein is bifurcated at top right. Frame $=$ location of $\mathbf{B}$. B. Detail of $\mathbf{A}$. Carbonate vein-fill is a microsparite with bands of varying crystal sizes parallel to the vein walls and inclusions of clayey host-sediment.

episodes at the very small scale would cause the chemical variations between these episodes to be subdued.

2. Most likely none of these minerals is a chemical end member, and widespread solid solutions between $\mathrm{Ca}-\mathrm{Mg}-\mathrm{Mn}$ (and $\mathrm{Fe}$ ) would also result in subdued chemical signals.

The second explanation is preferred here because SEM observations show that the different vein-fill episodes in G3 are in general well separated in distinct domains several tens of microns across, and because the mineralogical analyses indicate that all vein-fills are solid solutions of different minerals.

The cases of the $\mathrm{G1}^{\prime}$ and $\mathrm{G} 2^{\prime}$ carbonates defined above must be considered separately. They show mean values of $\mathrm{MnCO}_{3}$ slightly lower than those of G1 and G2 carbonates, associated with slightly higher mean values of $\mathrm{CaCO}_{3}$ and $\mathrm{MgCO}_{3}$ (Table 3). In fact, these mean values result from a mixing of values typical of $\mathrm{G} 1$ and $\mathrm{G} 2$ carbonates with values typical of G3 carbonate (Table 2). This probably indicates that fluid percolated through the clayey inclusions during the formation of G3 carbonate, which resulted in overgrowth of G1 and $\mathrm{G} 2$ crystals around the inclusions.

The material sampled with a microdrill for the mineralogical analyses was also analyzed for $\mathrm{Sr}, \mathrm{O}$, and $\mathrm{C}$ isotope ratios and for $\mathrm{Sr}$ concentrations. The results are given in Table 1 . The chemical and isotopic data of the low-Cl pore water at the décollement, Hole $948 \mathrm{C}$, that 

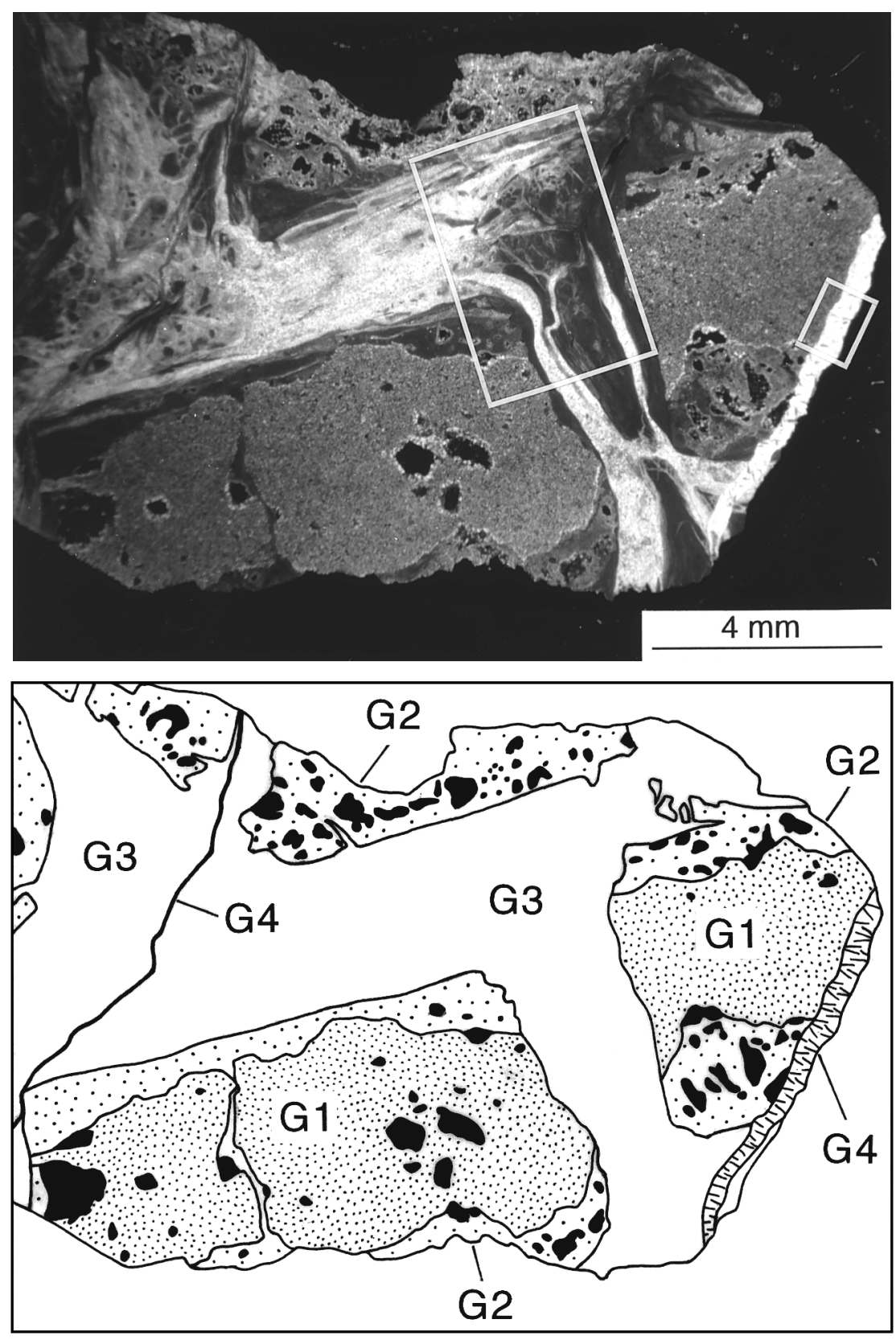

Figure 9. Type 4 carbonate veins, micrograph and sketch showing general microstructure (Sample 156948D-no.2). G1, G2, G3, and G4 are successive generations of vein-fill with cross-cutting relations. Black areas on the sketch are inclusions of clayey host-sediment in G1 and G2. G2 and G3 comprise numerous successive episodes of precipitation. In G3, the earliest episodes correspond to a micrite (black on the photograph), and the crystals became progressively larger with time, up to the microsparite size (white on the photograph) during the latest episodes. Frames $=$ location of Figure 12A (center) and Figure 13 (right). is reported in Table 1 for comparison are from Kastner and Zheng (Chapter 29, this volume). Because barite is highly insoluble, its presence as inclusions in the G3 micrite did not interfere with the geochemical and isotopic analyses performed.

The three most important features of the data in Table 1 are the following.

1. The carbonate of each vein-fill generation has a distinct chemical and isotopic composition.

2. The fluid (or fluids) from which they precipitated does not resemble the present-day in situ pore-water chemical and isotopic compositions. The carbonates are enriched in $\mathrm{Sr}$, have more radiogenic $\mathrm{Sr}$-isotope ratios, and different oxygen isotopes.

3. A trend of increasing Sr concentrations, an evolution from less to more radiogenic $\mathrm{Sr}$ isotopes, and an evolution from higher to lower oxygen and carbon isotope ratios from G1 through the late microsparite in G3 is evident.

Figure 14 emphasizes these results. It also shows how chemically and isotopically different both the pore waters and the vein carbonates of Hole $948 \mathrm{C}$ are from modern seawater composition.

\section{DISCUSSION}

\section{Mode of Vein Carbonate Precipitation}

Although Type 1, 2, and 3 veins show different microstructures, their carbonate fills display similar fundamental textural characteristics.

1. A micritic to microsparitic texture, made of crystals a few to 50 $\mu \mathrm{m}$ across. 

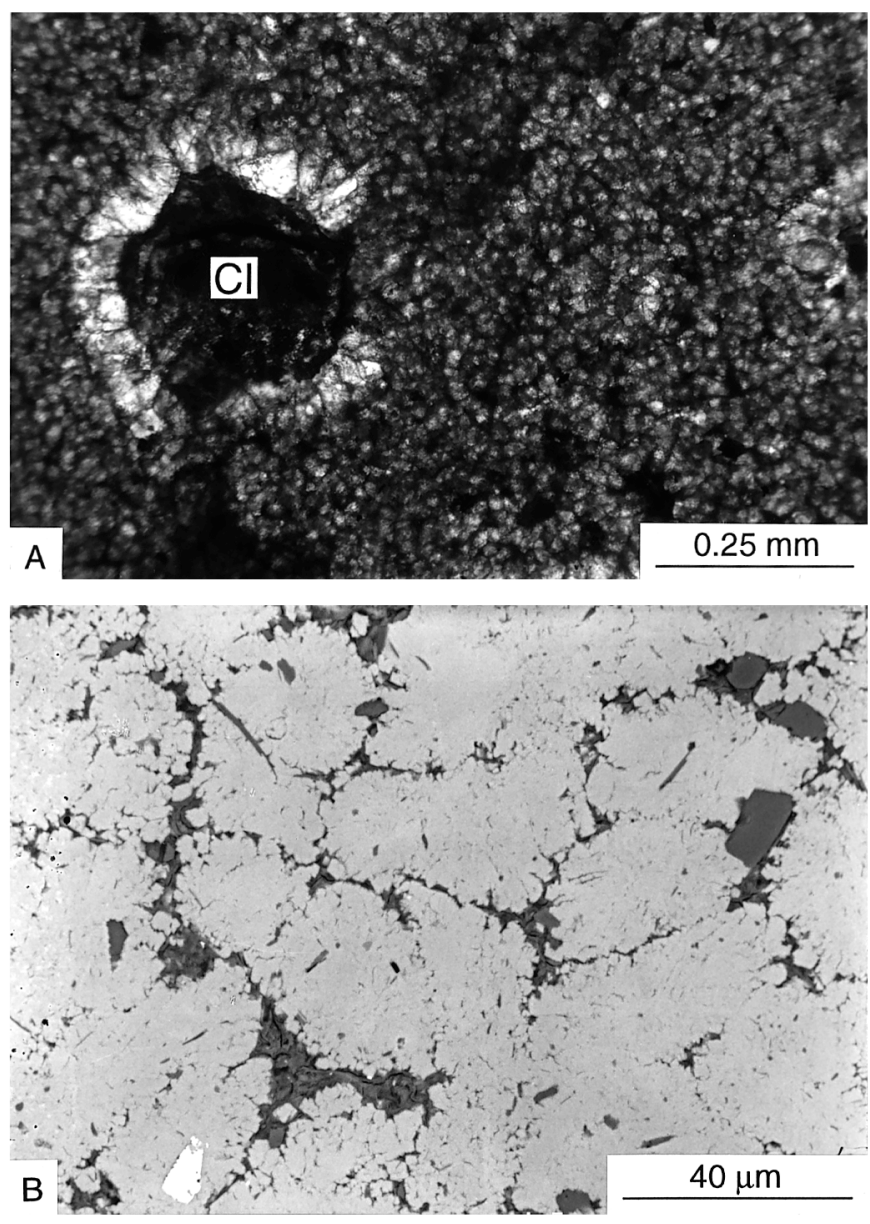

Figure 10. Type 4 carbonate veins, Generation 1 (G1) vein-fill characteristics (Sample 156-948D-no.3). A. Micrograph of microsparite texture in G1. Clayey host-sediment inclusions (CI) are bordered by larger and lighter crystals with palisade geometry. B. Backscattered SEM image of G1. Carbonate crystals (light gray) are spheroids formed of small, poorly connected rhombohedra. Clayey host-sediment is intercalated between the spheroids. Large detrital grains are quartz and feldspar (dark gray), and $\mathrm{Fe}$ and $\mathrm{Ti}$ oxides (white).

2. The smallest crystals $(<5 \mu \mathrm{m})$ are rhombohedra, whereas the larger crystals, although spheroidal, consist of rhombohedra agglomerates. The largest crystals have often a fibrous radial texture.

3. Crystals are either disconnected or poorly connected, the intervening space being filled by clayey host-sediment. The backscattered SEM images show that the sediment that is filling these spaces has been compacted by crystal growth, with formation of a planar fabric parallel to the crystal edges. Hostsediment is intercalated between the fibers in the external part of the large crystals with a radial fibrous texture.

These features show that crystal nucleation occurred at sites dispersed in the clay sediment with a few tens-of-microns spacing, and, as the spheroids grew, they became partially connected and crystallization pressure compacted the intervening sediment. The mode of growth is thus that of a cement, and not of classical fill of an open fracture.

Crystal growth was, however, structurally controlled by fractures, as indicated by (1) the macroscopic elongated geometry of veins, (2) the alignment of veins along macroscopic fractures in the case of Type 1 and 3 veins, (3) zoning with respect to carbonate crystal sizes that occur in stripes parallel to the vein walls of some veins, (4) the frequently sharp vein boundaries, and (5) alignment of disconnected crystals forming incipient, discontinuous microveins in Type 2 veins. In the latter veins, the irregular carbonate patches probably formed through thickening of these microveins, forming a connected network. The millimeter-size clayey inclusions in the patches represent the trapped host-sediment lenses that were bounded by the original fractures.

These observations indicate that the fluid from which the carbonate crystals precipitated circulated along fractures, but was able to percolate within the pores of the adjacent host-sediment, where precipitation was probably caused by the physical-chemical disequilibrium between the fluid and the sediment. This mode of precipitation may have been controlled by the poor lithification and high porosity of the host-sediment, which prevented fracture opening from being maintained, and facilitated fluid percolation from the fractures toward the adjacent host-sediment.

In Type 4 veins, G1 shows close textural analogies with Type 1, 2 , and 3 vein-fills, indicating crystal growth within the sediment (Fig. 15). However, the lack of information on the relations between Type 4 veins and their host-sediment does not permit us interpretation of the microstructural origin of Type 4 veins relative to the other three vein types.

In Type 4 veins, the transition from G1 to G2 marks a major change in the mode of vein formation (Fig. 15). Indeed, the voids between the carbonate crystals and the frequent organization of the different carbonate textures in bands parallel to the boundaries between G1 and G2 indicate that crystallization of G2 occurred in open fractures. The progressive disappearance of clayey host-sediment inclusions from the micrite to the microsparite indicates that clayey material was transported in the open fractures during the first period of precipitation (micrite), and that the fluid became progressively clearer. During the late period of precipitation (microsparite), inclusions were absent. The transition between $\mathrm{G} 1$ and $\mathrm{G} 2$ indicates that cementation of the host-sediment by G1 carbonate precipitation created rigid domains where fractures could have formed and stayed open during further fracturing.

G3 and G4 also correspond to precipitation in open fractures (Fig. $15)$; they are solid-inclusion free. Fracture surfaces are sharper and more regular than those between G1 and G2, indicating a more brittle behavior of the vein material.

\section{Relations with Sediment Deformation, Stress, and Fluid Regime}

We have seen above that precipitation of G2, G3, and G4 in Type 4 veins was related to episodic brittle fracturing (crack sealing) of clayey sediment previously cemented by G1 carbonates. The geometry of G3 shows contemporaneous opening of extensional fractures in different directions (Fig. 15). These observations suggest that formation of G2 to G4 in Type 4 veins occurred during dilatant episodes associated with pore pressures close to lithostatic pressure that were responsible for hydraulic fracturing.

Dilatancy may appear less obvious in Types 1, 2, and 3 veins and in G1 of Type 4 veins, because in them carbonate precipitation occurred within sediment that was compacted by crystal growth; the volume occupied by carbonate crystals may correspond to the porosity reduction. However, the carbonate/clayey host-sediment volume ratio is very high in most veins $(>80 \%)$, indicating that at least part of the volume occupied by carbonate crystals actually corresponds to bulk dilatancy. Dilatancy would have aided fluid circulation necessary for carbonate crystal growth. The distinctive feature of these veins is that the dilatancy was not restricted to the fractures, but affected a band of host-sediment along the fractures. As suggested above, this may be due to the poor lithification and high porosity of the host-sediment at the time of vein formation. In Type 2 veins, the microvein networks show that dilatancy occurred along fractures of 

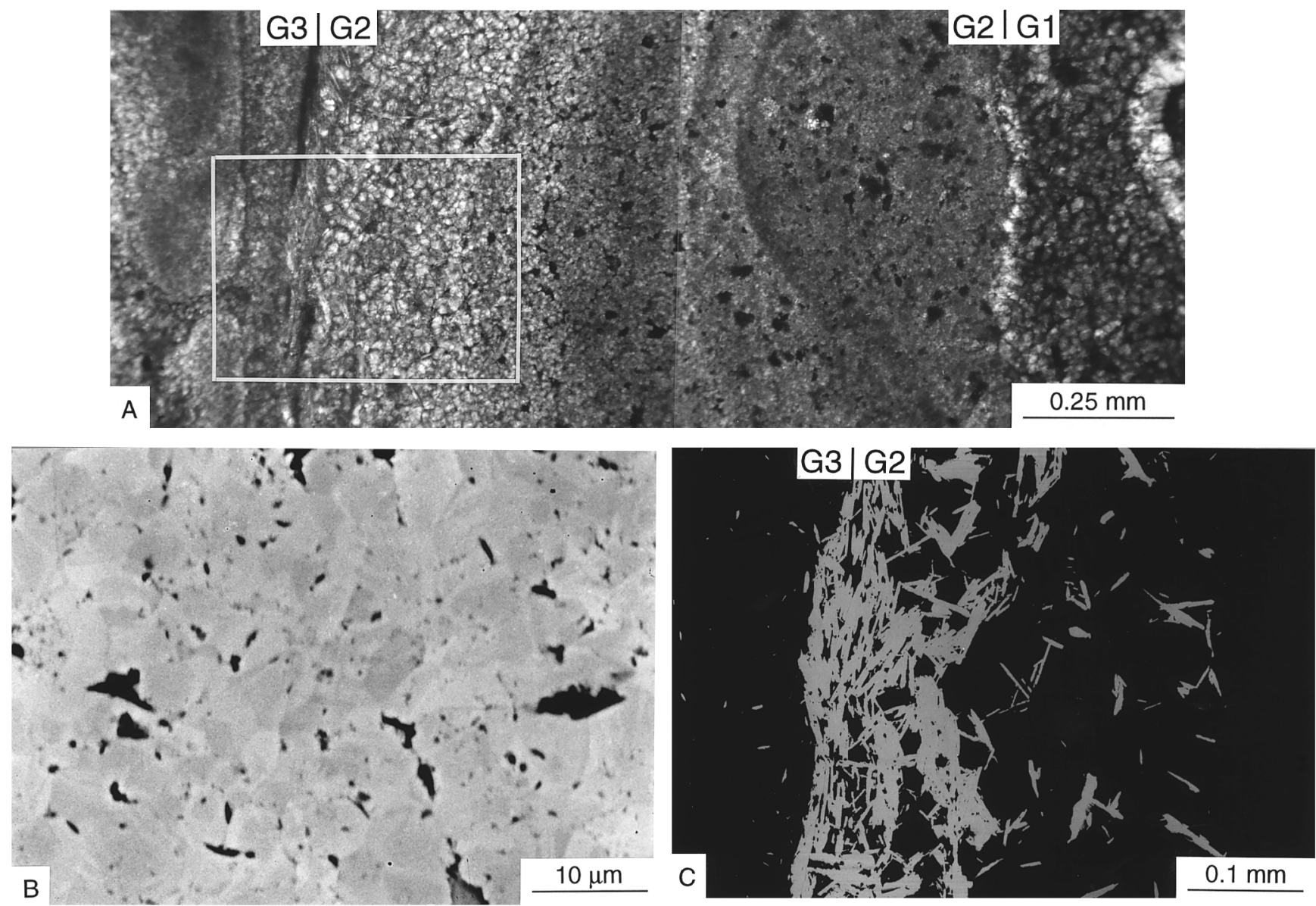

Figure 11. Type 4 carbonate veins, Generation 2 (G2) vein-fill characteristics (Sample 156-948D-no.3). A. Micrograph of G2 texture, with contacts with G1 (right; note the row of lighter crystals along the boundary) and G3 (left; vertical black stripe). G2 is formed by bands of varying grain sizes, passing from a gray micrite at right to a microsparite at left. Thin, elongated crystals in the microsparite are barite crystals close to the boundary with G3 (see $\mathbf{C}$ ). Frame $=$ location of C. B. Backscattered SEM image of medium-sized micrite texture in G2 (center-right part of A). Black = voids between carbonate crystals. C. Backscattered SEM image of G2 with prismatic barite crystals inclusions (in white; left part of $\mathbf{A}$ ). The left limit of barite concentration is the boundary with G3, in which barite crystals are rare and small.

different directions. In Type 1 veins, dilatancy occurred along scaly foliation surfaces that were formed as compactional features (clay particle reorientation associated with porosity collapse), as shown by SEM observations (Labaume et al., Chapter 4, this volume), which implies that dilatancy acted in the sense opposite to that of the compression responsible for the formation of the foliation. These observations suggest that formation of Type 1,2 , and 3 veins and G1 in Type 4 veins was also caused by high pore-pressure episodes.

In the case of Type 1 veins, incompatibility between compactional shear strain during the formation of scaly fabrics and dilatancy during the formation of veins requires that shear stress was relaxed when the veins formed. This implies cyclic variations of the stress regime, probably controlled by variations of pore pressure and associated with variations of permeability, which can be described as follows (Fig. 16).

1. Compactional shear strain is typical of normally to under-consolidated sediment (e.g., Moore et al., 1986; Hicher et al., 1994), and requires a significant shear stress (e.g., Moran and Christian, 1990). This implies a relatively low pore pressure in fault zones during the formation of the scaly fabrics (Fig. 16A). Compactional strain probably results in lowered permeability in the scaly-fabric zones.
2. Vein formation corresponds to episodes when fault zones are under high pore pressure, close to lithostatic. In this case, the stress is decoupled at the boundaries of the overpressured zone, and the compactional shear strain (formation of scaly fabrics) is inhibited. High pore pressure favors hydraulic fracturing associated with transient permeability increase in fault zones (the "dynamic permeability" of Stephenson et al., 1994; Brown et al., 1994), which results in the opening of pre-existing discontinuities (Type 1 veins along the scaly foliation; Fig. $16 \mathrm{~B})$, or in the formation of networks of neo-formed fractures in various directions in undeformed material at the periphery of the scaly fabric zones (i.e., the microvein networks in Type 2 veins, and the G3 openings in Type 4 veins). The dilatant intervals where veins occur correspond in scale and geometry to the "hydrofractures" inferred from the sharp localized density and resistivity anomalies revealed by logging while drilling in the décollement zone (Moore et al., 1995).

Elevated pore pressures favor displacement along fault zones (Hubbert and Rubey, 1959). Thus, displacement is likely to be more important during these episodes than during episodes of lowered pore pressure and formation of the scaly fabrics. This interpretation would account for the low fraction of the bulk sediment affected by clay- 

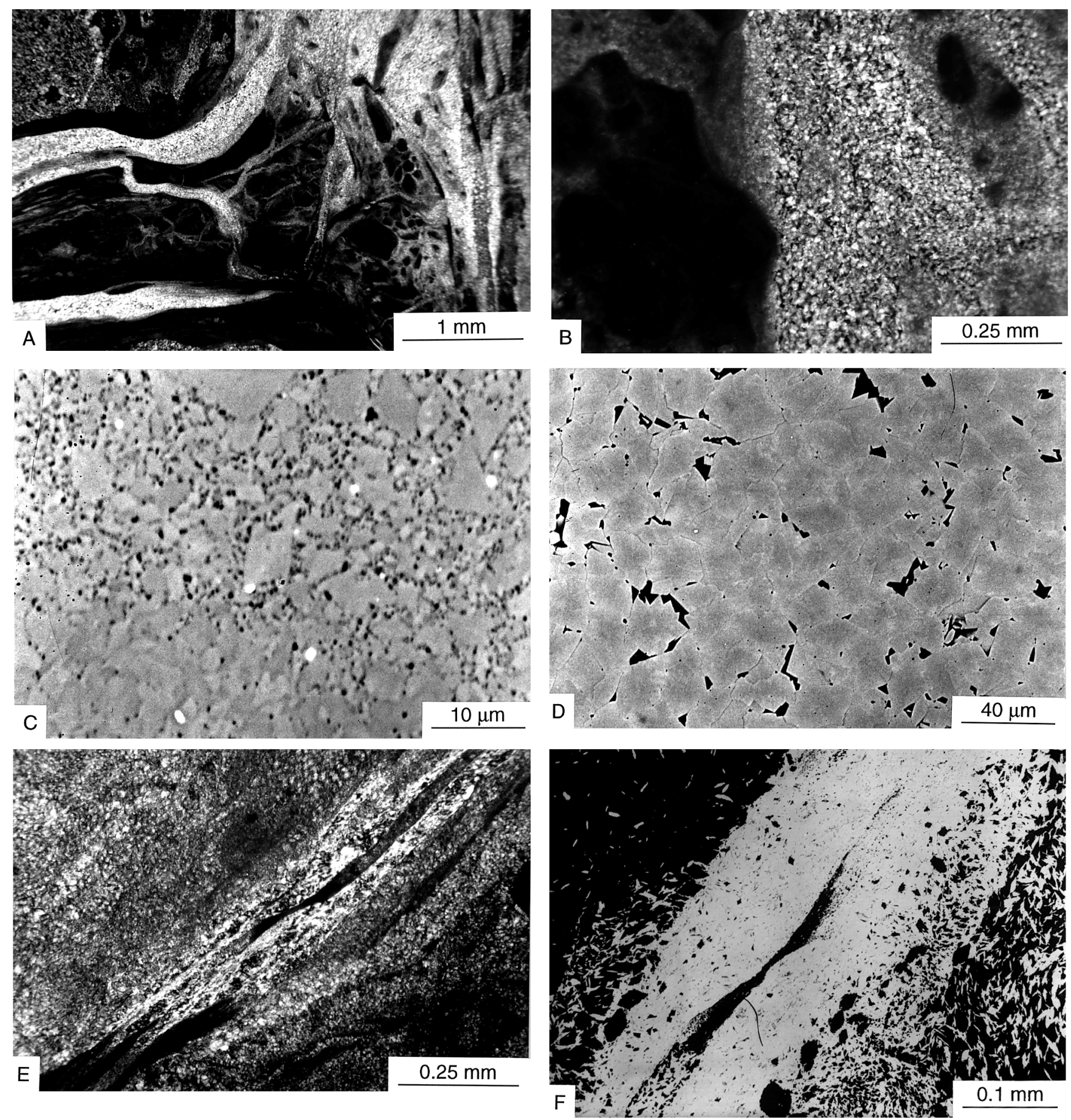

Figure 12. Type 4 carbonate veins, Generation 3 (G3) vein-fill characteristics. A. Micrograph showing G3 microstructure. Micrite (black) and microsparite (white) form parallel bands (left) passing to brecciated texture (right; G1 and G2 appear at upper left corner; Sample 156-948D-no.2, detail of Fig. 9). B. Micrograph showing detail of G3 texture with micrite (black) and microsparite (white; Sample 156-948D-no.3). C. Backscattered SEM image of micrite texture in G3 with rare inclusions of small barite crystals (white; left part of $\mathbf{B}$ ). Black = voids between carbonate crystals. D. Backscattered SEM image of microsparite texture in G3 (center of B). Black = voids between carbonate crystals. E. Micrograph of barite vein across G3 carbonate (Sample 156-948D-no.2). F. Backscattered SEM image of barite vein (light gray) across G3 carbonate (black; same area as $\mathbf{E}$ ).

particle reorientation in fault zones (Labaume et al., Chapter 4, this volume).

\section{Evolution of Fluid Composition}

The chemical and isotopic data of Table 1 clearly indicate that the vein carbonates have precipitated from a fluid that is chemically and isotopically distinct from the present-day in situ pore water, or from the contemporaneous seawater. The observed chemical and isotopic evolution trends from the early to later generations of carbonates sampled with a microdrill in Type 4 veins (i.e., G1, and the micrite and late microsparite in G3) from lower to higher $\mathrm{Sr}$ concentrations, from less to more radiogenic $\mathrm{Sr}$ isotopes, and from heavier to lighter oxygen and carbon isotopes, indicate that these three carbonate gen- 


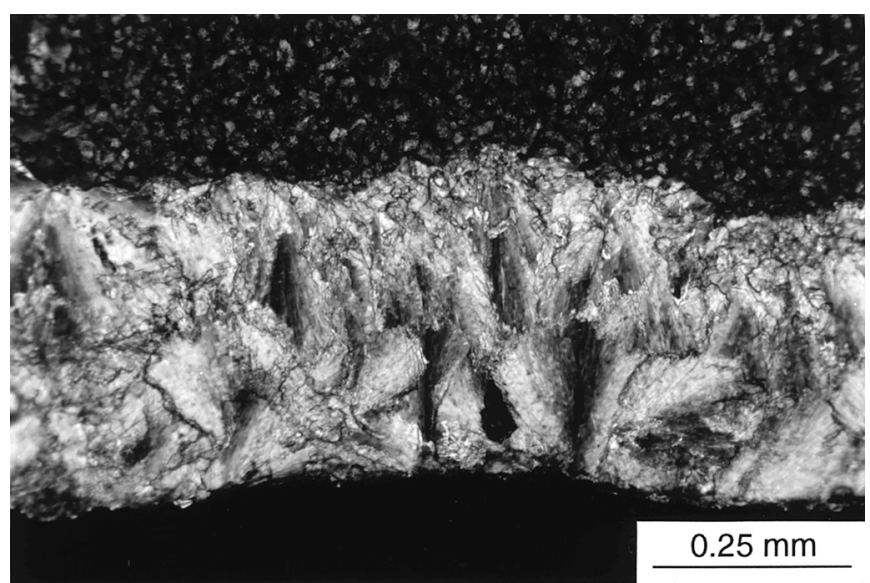

Figure 13. Type 4 carbonate veins, Generation 4 (G4) vein-fill characteristics (micrograph). Vein-fill has a divergent fibrous texture, indicating syntaxial growth (upper wall $=\mathrm{G} 1$, lower wall $=$ sample border; Sample 156-948Dno.2, detail of Fig. 9).

erations represent different mixing ratios between the in situ pore water and a deep-sourced injected fluid. The mixing ratio decreases from $\mathrm{G} 1$ to the late microsparite in G3. The fluid from which the late microsparite (dolomite plus Mg-kutnohorite) precipitated is the least diluted by the in situ pore water, which is strongly overprinted by volcanic glass diagenesis. The pristine injected fluid must have originated arcward from greater depths where higher temperatures prevail, and where fluid-rock interactions are more intense (for discussion, see Kastner and Zheng, Chapter 29, this volume, and Zheng and Kastner, Chapter 12, this volume). This fluid, with its significantly more radiogenic $\mathrm{Sr}$ isotopic composition than the in situ pore water, suggests a stronger influence of the detrital components of the sediment on the fluid chemistry, typical at higher temperature fluid-rock reactions.

The negative carbon isotopes of all vein carbonates, and especially the very low carbon isotope ratios of the late microsparite in $\mathrm{G} 3$, indicate that the fluid-rock reactions involve an organic-rich sediment not encountered by drilling to almost $600 \mathrm{mbsf}$ at Site 948 . That the fluid from which the vein carbonates precipitated has reacted with a sediment enriched in organic matter is further supported by the dissolved-sulfate concentration depth profile (Shipley, Ogawa, Blum, et al., 1995), and by the trace element concentrations of especially Mo, $\mathrm{Zn}$, I, and Br, of the low-Cl fluid of Hole 948C (Zheng and Kastner, Chapter 12, this volume, and Kastner and Zheng, Chapter 29, this volume)

Because the oxygen isotopic composition of the source fluid of the vein carbonates is unknown, the data in Table 1 cannot simply be used for temperature-of-formation calculations. Modeling of the oxygen isotope data is in progress.

\section{CONCLUSIONS}

Carbonate veins, mostly made of rhodochrosite and/or Mg-kutnohorite, are relatively common in and, mostly, above the décollement zone at the toe of the northern Barbados accretionary prism. Most of them are spatially associated with fault zones.

Four vein types have been classified on the basis of their microstructural associations.

1. Type 1 veins occur in the scaly-fabric zones where shear strain and tectonic displacement are concentrated.

2. Type 2 veins occur across weakly fractured sediment at the periphery of the scaly-fabric zones.
3. Type 3 veins occur along microfaults; they are not closely associated with scaly-fabric zones at the core scale, but occur a few meters above a major thrust fault.

4. Type 4 veins, which probably originate from immediately above the décollement, but whose relationships with the hostsediment are unknown. Type 4 veins show a complex microstructural evolution indicating that they formed during numerous successive episodes of fracture opening and carbonate precipitation (crack sealing).

Microstructures of all vein types indicate that vein formation corresponds to dilatancy episodes during which high pore pressure favored hydraulic fracturing and permeability increase and inhibited compactional shear strain in the scaly-fabric zones.

In Type 1 to 3 veins, and in the first generation (G1) vein-fill in Type 4 veins, carbonate precipitated as spheroidal crystals. These crystals did not nucleate in open fractures, but grew as a cement within a millimeter-thick band of sediment along the fractures, probably due to the high porosity of the clayey host-sediment. In Type 4 veins, the sediment cemented by G1 carbonate became rigid enough to fracture, and for these fractures to be held open during later episodes of vein formation (G2, G3, and G4).

The chemistry and isotopic composition of the vein carbonates in Type 4 veins indicate that they precipitated from a non-in situ fluid that was injected from a deeper and hotter arcward source. The extent of mixing between the exotic fluid and the in situ pore water decreased from $\mathrm{G} 1$ to the late microsparite (dolomite plus $\mathrm{Mg}$ kutnohorite) in G3, when it peaked, producing the lower ratio of in situ pore water to vein fluid geochemical signatures. The late dolomite plus Mg-kutnohorite in G3 represents the final, most pristine subpulse of fluid injection of this episodic fluid-flow event along the Barbados décollement, which must have influenced the thermal regime. The present-day pore fluid is highly overprinted by in situ diagenetic reactions with volcanic glass, suggesting that a major fluidflow episode has not occurred recently.

In conclusion, both the microstructures and chemical features indicate that the carbonate vein formation is controlled by episodic injection of overpressured fluid originating from deeper horizons along fault zones, inhibiting compactional shear strain and causing hydrofracturing, permeability increase, and mineralization.

\section{ACKNOWLEDGMENTS}

We would like to thank the technical staffs of the Universities of Wales, Aberystwyth (T. Ridgeway) and Montpellier II, France, and of Scripps Institution of Oceanography, for making thin sections in this difficult material. X. Garcia Veigas (Serveis Científico-Tècnics of the Barcelona University) helped with the electron microprobe analyses. This work was supported by INSU-CNRS, Contrat Geosciences Marines to P. Labaume, and the National Science Foundation through the United States Committee (JOI-USSAC) program to M. Kastner. The manuscript was greatly improved by comments from $\mathrm{H}$. Tobin and the ODP staff.

\section{REFERENCES}

Brown, K.M., Bekins, B., Clennell, B., Dewhurst, D., and Westbrook, G., 1994. Heterogeneous hydrofracture development and accretionary fault dynamics. Geology, 22:259-262.

Hicher, P.Y., Wahyudi, H., and Tessier, D., 1994. Microstructural analysis of strain localization in clay. Comput. Geotech., 16:205-222.

Hubbert, M.K., and Rubey, W.W., 1959. Role of fluid pressure in mechanics of overthrust faulting, Part 1. Mechanics of fluid-filled porous solids and its application to overthrust faulting. Geol. Soc. Am. Bull., 70:115-166.

Mascle, A., Moore, J.C., et al., 1988. Proc. ODP, Init. Repts., 110: College Station, TX (Ocean Drilling Program).

McCrea, J.M., 1950. On the isotopic chemistry of carbonates and a paleotemperature scale. J. Chem. Phys., 18:849-857. 
Moore, J.C., Shipley, T.H., Goldberg, D., Ogawa, Y., Filice, F., Fisher, A., Jurado, M.-J., Moore, G.F., Rabaute, A., Yin, H., Zwart, G., and Bruckmann, W., 1995. Abnormal fluid pressures and fault-zone dilation in the Barbados accretionary prism: evidence from logging while drilling. Geology, 23:605-608

Moore, J.C., Roeske, S.M., Lundberg, N., Schoonmaker, J., Cowan, D.S., Gonzales, E., and Lucas, S.E., 1986. Scaly fabrics from Deep Sea Drilling Project cores from forearcs. In Moore J.C. (Ed.), Structural Fabric in Deep Sea Drilling Project Cores From Forearcs. Mem.-Geol. Soc. Am., 166:55-73.

Moore, J.C., and Vrolijk, P., 1992. Fluids in accretionary prisms. Rev. Geophys., 30:113-135.

Moran K., and Christian, H.A., 1990. Strength and deformation behavior of sediment from the Lesser Antilles forearc accretionary prism. In Moore, J.C., Mascle, A., et al., Proc. ODP, Sci. Results, 110: College Station, TX (Ocean Drilling Program), 279-288.

Ramsay, J.G, and Huber, M.I., 1983. The Techniques of Modern Structural Geology (Vol. 1): Strain Analysis: London (Acad. Press).

Sample, J.C., and Kopf, A., 1995. Isotope geochemistry of syntectonic carbonate cements and veins from the Oregon Margin: implications for the hydrogeologic evolution of the accretionary wedge. In Carson, B., Westbrook, G.K., Musgrave, R.J., and Suess, E. (Eds.), Proc. ODP, Sci.
Results, 146 (Pt. 1): College Station, TX (Ocean Drilling Program), 137148.

Shipboard Scientific Party, 1994. Site 892. In Westbrook, G.K., Carson, B., Musgrave, R.J., et al., Proc. ODP, Init. Repts., 146 (Pt. 1): College Station, TX (Ocean Drilling Program), 301-378.

Shipley, T.H., Ogawa, Y., Blum, P., et al., 1995. Proc. ODP, Init. Repts., 156: College Station, TX (Ocean Drilling Program).

Stephenson, E.L., Maltman, A.J., and Knipe, R.J., 1994. Fluid flow in actively deforming sediments: "dynamic permeability" in accretionary prisms. In Parnell, J. (Ed.), Geofluids: Origin, Migration, and Evolution of Fluids in Sedimentary Basins. Geol. Soc. Spec. Publ. London, 78:113125.

Vrolijk P., and Sheppard, S.M.F., 1991. Syntectonic carbonate veins from the Barbados accretionary prism (ODP Leg 110): record of paleohydrology. Sedimentology, 38:671-690.

Date of initial receipt: 1 February 1996

Date of acceptance: 28 August 1996

Ms 156SR-012

Table 1. Mineralogy, strontium concentrations, and strontium, oxygen, and carbon isotopic compositions of Generation 1 and 3 ca rbonates in Type 4 veins (Hole 948D).

\begin{tabular}{|c|c|c|c|c|c|c|c|}
\hline Macro-appearance & Generation & Mineralogy & $\begin{array}{c}\mathrm{Sr} \\
(\mathrm{ppm})\end{array}$ & ${ }^{87} \mathrm{Sr} /{ }^{86} \mathrm{Sr}$ & $2 \sigma$ & $\begin{array}{c}\delta^{18} \mathrm{O} \\
(\% \circ \mathrm{PDB})\end{array}$ & $\begin{array}{c}\delta^{13} \mathrm{C} \\
(\% \circ \mathrm{PDB})\end{array}$ \\
\hline Gray & G1 & $\begin{array}{l}\text { Rhodochrosite \& } \\
\text { Mg-kutnohorite }\end{array}$ & 23 & 0.708131 & 16 & $\begin{array}{l}5.21 \\
5.31\end{array}$ & $\begin{array}{l}-3.30 \\
-3.29\end{array}$ \\
\hline Pink & $\begin{array}{l}\text { G3 } \\
\text { (micrite) }\end{array}$ & $\begin{array}{l}\text { Mg-kutnohorite \& } \\
\text { rhodochrosite }\end{array}$ & 428 & $\begin{array}{l}0.708385 \\
0.708320\end{array}$ & $\begin{array}{l}16 \\
13 \\
15\end{array}$ & $\begin{array}{l}3.61 \\
3.60 \\
3.65\end{array}$ & $\begin{array}{l}-5.97 \\
-7.16\end{array}$ \\
\hline White & $\begin{array}{l}\text { G3-late } \\
\text { (microsparite) }\end{array}$ & $\begin{array}{l}\text { Dolomite \& } \\
\text { Mg-kutnohorite }\end{array}$ & $\begin{array}{l}420 \\
868\end{array}$ & 0.708567 & 16 & $\begin{array}{l}5.05 \\
3.09 \\
3.09\end{array}$ & $\begin{array}{l}-1.10 \\
-9.33 \\
*-8.91\end{array}$ \\
\hline Décollement pore water & & & 16 & 0.707336 & 17 & -2.09 & \\
\hline
\end{tabular}

Note: $*$ = very little gas. 
Table 2. Major element electron microprobe analyses on Type 4 vein-fills (Hole 948D).

\begin{tabular}{|c|c|c|c|c|}
\hline Generation & $\begin{array}{c}\text { Sample } \\
\text { 156-948D-no. }\end{array}$ & $\begin{array}{l}\mathrm{MgCO}_{3} \\
(\mathrm{~mol} \%)\end{array}$ & $\begin{array}{l}\mathrm{CaCO}_{3} \\
(\mathrm{~mol} \%)\end{array}$ & $\begin{array}{l}\mathrm{MnCO}_{3} \\
(\mathrm{~mol} \%)\end{array}$ \\
\hline G1 & $1 \mathrm{a}$ & 7.48 & 8.55 & 83.10 \\
\hline G1 & $1 \mathrm{a}$ & 7.37 & 10.99 & 81.34 \\
\hline G1 & $1 \mathrm{a}$ & 7.13 & 9.21 & 83.30 \\
\hline G1 & 1a & 7.64 & 12.25 & 79.58 \\
\hline G1 & la & 7.99 & 13.45 & 78.14 \\
\hline G1 & $1 \mathrm{a}$ & 7.55 & 12.95 & 78.87 \\
\hline G1 & $1 \mathrm{a}$ & 6.42 & 7.21 & 85.80 \\
\hline G1 & 1a & 6.74 & 7.79 & 85.00 \\
\hline G1 & 1a & 8.28 & 12.04 & 79.44 \\
\hline G1 & 1a & 7.99 & 11.10 & 80.69 \\
\hline G1 & $1 \mathrm{a}$ & 8.29 & 13.18 & 78.08 \\
\hline G1 & $1 \mathrm{a}$ & 9.10 & 12.20 & 77.98 \\
\hline G1 & 1a & 8.31 & 11.59 & 79.51 \\
\hline G1 & 1a & 7.80 & 13.21 & 78.41 \\
\hline G1 & $2 b$ & 6.62 & 8.76 & 83.97 \\
\hline G1 & $2 b$ & 6.96 & 8.81 & 83.85 \\
\hline G1 & $2 b$ & 6.93 & 8.05 & 84.57 \\
\hline G1 & $2 b$ & 6.66 & 8.19 & 84.63 \\
\hline G1 & $2 b$ & 8.33 & 10.54 & 80.66 \\
\hline G1 & $2 b$ & 7.07 & 8.25 & 84.04 \\
\hline G1 & $2 b$ & 6.41 & 5.97 & 87.29 \\
\hline G1 & $2 b$ & 7.23 & 9.26 & 83.23 \\
\hline G1 & $2 b$ & 7.42 & 8.25 & 84.05 \\
\hline G1 & $2 b$ & 8.64 & 10.47 & 80.51 \\
\hline G1 & $2 b$ & 7.98 & 11.26 & 80.44 \\
\hline G1 & $2 b$ & 6.72 & 9.42 & 83.35 \\
\hline G1 & $2 b$ & 7.12 & 7.69 & 84.91 \\
\hline G1 & $2 b$ & 6.91 & 8.37 & 84.40 \\
\hline G1 & $2 b$ & 7.49 & 9.25 & 83.09 \\
\hline G1 & $3 a$ & 6.78 & 8.45 & 84.06 \\
\hline G1 & $3 a$ & 7.52 & 10.15 & 82.02 \\
\hline G1 & $3 a$ & 8.72 & 12.00 & 79.07 \\
\hline G1 & $3 a$ & 8.65 & 11.91 & 79.33 \\
\hline G1 & $3 a$ & 6.85 & 7.01 & 85.60 \\
\hline G1 & $3 a$ & 6.83 & 8.15 & 84.47 \\
\hline G1 & $3 a$ & 7.73 & 11.65 & 80.24 \\
\hline G1 & $3 a$ & 7.05 & 7.85 & 84.78 \\
\hline G1 & $3 a$ & 7.99 & 10.93 & 80.75 \\
\hline G1 & $3 a$ & 7.62 & 11.46 & 80.39 \\
\hline G1 & $5 a$ & 8.52 & 11.74 & 79.38 \\
\hline G1 & $5 \mathrm{a}$ & 8.03 & 12.29 & 79.35 \\
\hline G1 & $5 a$ & 6.91 & 9.94 & 82.67 \\
\hline G1 & $5 \mathrm{a}$ & 7.41 & 8.08 & 83.94 \\
\hline G1 & $5 \mathrm{a}$ & 6.83 & 9.71 & 83.16 \\
\hline G1 & $5 a$ & 7.72 & 8.49 & 83.47 \\
\hline G1 & $5 \mathrm{a}$ & 6.65 & 7.01 & 86.01 \\
\hline G1 & $5 a$ & 7.25 & 9.77 & 82.66 \\
\hline G1 & $5 a$ & 7.98 & 8.87 & 82.70 \\
\hline G1 & $5 a$ & 6.72 & 9.23 & 83.36 \\
\hline G1 & $5 a$ & 8.30 & 10.96 & 80.40 \\
\hline G1 & $5 a$ & 6.67 & 10.17 & 82.69 \\
\hline G1 & $5 a$ & 6.91 & 9.70 & 82.72 \\
\hline G1 & $5 a$ & 6.58 & 8.22 & 84.63 \\
\hline G1 & $5 a$ & 7.46 & 8.62 & 83.20 \\
\hline G1 & $5 \mathrm{a}$ & 7.38 & 10.25 & 80.45 \\
\hline G1 & $5 a$ & 6.72 & 9.77 & 82.85 \\
\hline G1 & $5 a$ & 7.34 & 10.47 & 81.76 \\
\hline G1 & $5 a$ & 6.59 & 7.06 & 86.08 \\
\hline G1 & $5 a$ & 7.29 & 10.37 & 82.09 \\
\hline G1 & $5 a$ & 7.10 & 9.38 & 83.24 \\
\hline G1 & $5 a$ & 7.49 & 9.21 & 82.58 \\
\hline G1 & $5 \mathrm{a}$ & 8.02 & 10.38 & 81.19 \\
\hline G1', & $2 b$ & 8.53 & 13.07 & 78.05 \\
\hline G1', & $2 b$ & 7.46 & 12.28 & 79.99 \\
\hline G1 ${ }^{\prime}$ & $2 b$ & 9.24 & 19.72 & 70.66 \\
\hline G1', & $2 b$ & 8.17 & 12.79 & 78.73 \\
\hline G1', & $2 b$ & 7.22 & 8.40 & 84.19 \\
\hline G1', & $3 a$ & 7.89 & 13.97 & 77.79 \\
\hline G1', & $3 a$ & 8.06 & 20.12 & 71.29 \\
\hline G1', & $3 a$ & 6.97 & 10.34 & 82.35 \\
\hline G1', & $3 a$ & 8.48 & 10.00 & 80.94 \\
\hline G1', & $3 a$ & 8.27 & 10.51 & 81.02 \\
\hline G1', & $3 a$ & 6.97 & 8.38 & 84.32 \\
\hline $\mathrm{G} 1^{\prime}$ & $3 a$ & 6.93 & 5.99 & 86.62 \\
\hline $\mathrm{G} 1^{\prime}$ & $3 a$ & 7.61 & 10.46 & 81.70 \\
\hline $\mathrm{G} 1^{\prime}$ & $3 a$ & 7.80 & 13.68 & 78.21 \\
\hline G1', & $3 a$ & 7.61 & 10.45 & 81.62 \\
\hline G1', & $3 a$ & 6.81 & 7.21 & 85.37 \\
\hline G1', & $5 a$ & 7.76 & 10.06 & 81.67 \\
\hline G1', & $5 a$ & 7.77 & 9.61 & 82.15 \\
\hline $\mathrm{G} 1^{\prime}$ & $5 a$ & 8.06 & 23.18 & 68.34 \\
\hline $\mathrm{G} 1^{\prime}$ & $5 a$ & 9.17 & 20.88 & 69.74 \\
\hline $\mathrm{G} 1^{\prime}$, & $5 a$ & 9.14 & 16.20 & 74.32 \\
\hline G1' & $5 a$ & 8.81 & 14.47 & 76.37 \\
\hline G1', & $5 a$ & 8.68 & 15.22 & 75.66 \\
\hline G1' & $5 a$ & 7.51 & 9.00 & 82.97 \\
\hline $\mathrm{G} 1^{\prime}$ & $5 a$ & 8.44 & 13.03 & 78.22 \\
\hline
\end{tabular}

\begin{tabular}{|c|c|c|c|c|}
\hline Generation & $\begin{array}{c}\text { Sample } \\
\text { 156-948D-no. }\end{array}$ & $\begin{array}{l}\mathrm{MgCO}_{3} \\
(\mathrm{~mol} \%)\end{array}$ & $\begin{array}{l}\mathrm{CaCO}_{3} \\
(\mathrm{~mol} \%)\end{array}$ & $\begin{array}{l}\mathrm{MnCO}_{3} \\
(\mathrm{~mol} \%)\end{array}$ \\
\hline G2 & $2 b$ & 7.08 & 6.54 & 85.99 \\
\hline G2 & $2 b$ & 6.84 & 9.46 & 83.47 \\
\hline $\mathrm{G} 2$ & $2 b$ & 8.38 & 13.02 & 77.99 \\
\hline G2 & $2 b$ & 7.50 & 9.66 & 82.48 \\
\hline G2 & $2 b$ & 7.39 & 10.23 & 82.13 \\
\hline $\mathrm{G} 2$ & $2 \mathrm{~b}$ & 7.17 & 8.24 & 83.94 \\
\hline G2 & $2 b$ & 6.65 & 7.65 & 85.27 \\
\hline $\mathrm{G} 2$ & $2 b$ & 6.82 & 6.95 & 85.79 \\
\hline G2 & $2 b$ & 6.87 & 7.16 & 85.72 \\
\hline G2 & $2 b$ & 7.59 & 9.02 & 82.79 \\
\hline $\mathrm{G} 2$ & $2 b$ & 7.50 & 8.12 & 84.14 \\
\hline $\mathrm{G} 2$ & $3 a$ & 7.18 & 8.75 & 83.46 \\
\hline $\mathrm{G} 2$ & $3 a$ & 7.59 & 11.54 & 80.45 \\
\hline $\mathrm{G} 2$ & $3 a$ & 8.57 & 12.16 & 78.83 \\
\hline $\mathrm{G} 2$ & $3 a$ & 7.80 & 11.60 & 80.03 \\
\hline $\mathrm{G} 2$ & $3 a$ & 8.44 & 10.54 & 80.13 \\
\hline $\mathrm{G} 2$ & $3 a$ & 7.51 & 9.59 & 82.44 \\
\hline G2 & $3 a$ & 7.33 & 10.00 & 82.01 \\
\hline $\mathrm{G} 2$ & $3 a$ & 7.23 & 6.77 & 85.30 \\
\hline G2 & $3 a$ & 7.12 & 6.97 & 84.84 \\
\hline $\mathrm{G} 2$ & $3 a$ & 8.86 & 13.94 & 76.75 \\
\hline $\mathrm{G} 2$ & $3 a$ & 8.31 & 12.21 & 79.14 \\
\hline G2 & $3 a$ & 7.84 & 11.68 & 80.03 \\
\hline $\mathrm{G} 2$ & $3 a$ & 7.19 & 7.00 & 85.09 \\
\hline $\mathrm{G} 2$ & $3 a$ & 6.35 & 5.70 & 87.41 \\
\hline G2 & $3 a$ & 7.28 & 10.40 & 82.05 \\
\hline $\mathrm{G} 2$ & $3 a$ & 7.45 & 10.13 & 82.16 \\
\hline G2 & $3 a$ & 6.66 & 5.86 & 86.92 \\
\hline $\mathrm{G} 2$ & $3 a$ & 7.73 & 10.26 & 81.81 \\
\hline $\mathrm{G} 2$ & $3 a$ & 7.26 & 10.49 & 81.90 \\
\hline G2 & $3 a$ & 7.38 & 10.51 & 81.87 \\
\hline $\mathrm{G} 2$ & $3 a$ & 7.42 & 6.91 & 85.29 \\
\hline G2 & $3 a$ & 7.91 & 12.81 & 79.16 \\
\hline $\mathrm{G} 2$ & $3 a$ & 6.66 & 7.06 & 85.72 \\
\hline $\mathrm{G} 2$ & $3 a$ & 6.86 & 7.68 & 85.11 \\
\hline G2 & $3 a$ & 6.45 & 5.52 & 87.68 \\
\hline $\mathrm{G} 2$ & $3 a$ & 7.26 & 7.57 & 84.92 \\
\hline G2 & $3 a$ & 7.50 & 9.12 & 83.01 \\
\hline G2 & $3 a$ & 7.16 & 8.72 & 83.91 \\
\hline $\mathrm{G} 2$ & $3 a$ & 6.85 & 6.14 & 86.57 \\
\hline $\mathrm{G} 2$ & $5 a$ & 7.87 & 10.88 & 80.97 \\
\hline G2 & $5 a$ & 7.89 & 11.49 & 80.26 \\
\hline $\mathrm{G} 2$ & $5 a$ & 6.64 & 6.71 & 86.19 \\
\hline G2 & $5 a$ & 8.60 & 13.29 & 77.64 \\
\hline $\mathrm{G} 2$ & $5 a$ & 6.56 & 8.59 & 84.38 \\
\hline $\mathrm{G} 2$ & $5 a$ & 6.83 & 5.60 & 87.34 \\
\hline G2 & $5 a$ & 7.48 & 8.05 & 84.25 \\
\hline $\mathrm{G} 2$ & $5 a$ & 6.89 & 7.08 & 85.78 \\
\hline G2 & $5 a$ & 7.43 & 9.67 & 82.66 \\
\hline G2 & $5 a$ & 7.52 & 9.86 & 82.41 \\
\hline $\mathrm{G} 2$ & $5 a$ & 7.63 & 9.93 & 81.95 \\
\hline G2 & $5 a$ & 6.92 & 7.42 & 85.31 \\
\hline $\mathrm{G} 2$ & $5 a$ & 6.52 & 5.43 & 87.77 \\
\hline G2 & $5 a$ & 7.86 & 13.00 & 78.78 \\
\hline G2 & $5 a$ & 8.18 & 9.61 & 81.79 \\
\hline $\mathrm{G} 2$ & $5 a$ & 8.11 & 10.16 & 81.41 \\
\hline $\mathrm{G} 2$ & $5 a$ & 8.23 & 13.71 & 77.60 \\
\hline G2 & $5 a$ & 8.37 & 13.35 & 77.90 \\
\hline $\mathrm{G} 2$ & $5 a$ & 8.02 & 12.12 & 79.61 \\
\hline $\mathrm{G} 2^{\prime}$ & $5 a$ & 8.67 & 12.96 & 78.01 \\
\hline $\mathrm{G} 2^{\prime}$ & $5 a$ & 7.27 & 8.64 & 83.37 \\
\hline $\mathrm{G} 2^{\prime}$ & $5 a$ & 7.67 & 12.85 & 79.06 \\
\hline $\mathrm{G} 2^{\prime}$ & $5 a$ & 7.51 & 8.13 & 83.95 \\
\hline $\mathrm{G} 2^{\prime}$ & $5 a$ & 9.03 & 16.12 & 74.36 \\
\hline $\mathrm{G} 2^{\prime}$ & $5 a$ & 9.27 & 15.52 & 74.97 \\
\hline $\mathrm{G} 2^{\prime}$ & $5 a$ & 8.38 & 13.98 & 77.32 \\
\hline $\mathrm{G} 2^{\prime}$ & $5 a$ & 8.92 & 16.35 & 74.50 \\
\hline $\mathrm{G} 2^{\prime}$ & $5 a$ & 9.55 & 23.11 & 67.00 \\
\hline $\mathrm{G} 2^{\prime}$ & $5 a$ & 9.29 & 18.14 & 72.29 \\
\hline $\mathrm{G} 2^{\prime}$ & $5 a$ & 8.18 & 12.36 & 79.17 \\
\hline $\mathrm{G} 2^{\prime}$ & $5 a$ & 7.15 & 9.16 & 83.53 \\
\hline G3 & 1a & 8.78 & 20.13 & 70.75 \\
\hline G3 & 1a & 9.37 & 19.58 & 70.72 \\
\hline G3 & 1a & 8.88 & 20.94 & 69.78 \\
\hline G3 & 1a & 8.49 & 21.76 & 69.21 \\
\hline G3 & 1a & 6.18 & 21.10 & 72.39 \\
\hline G3 & 1a & 8.40 & 14.24 & 76.88 \\
\hline G3 & 1a & 8.29 & 13.85 & 77.36 \\
\hline G3 & 1a & 8.18 & 9.69 & 81.41 \\
\hline G3 & la & 8.71 & 15.28 & 75.51 \\
\hline G3 & 1a & 8.85 & 15.90 & 74.82 \\
\hline G3 & 1a & 8.27 & 14.98 & 76.16 \\
\hline G3 & $1 \mathrm{a}$ & 8.53 & 14.91 & 76.15 \\
\hline G3 & 1a & 8.64 & 14.69 & 76.23 \\
\hline G3 & 1a & 8.16 & 11.40 & 79.84 \\
\hline G3 & 1a & 7.58 & 10.65 & 81.18 \\
\hline G3 & 1a & 8.95 & 17.05 & 73.58 \\
\hline
\end{tabular}


Table 2 (continued).

\begin{tabular}{|c|c|c|c|c|}
\hline Generation & $\begin{array}{c}\text { Sample } \\
\text { 156-948D-no. }\end{array}$ & $\begin{array}{l}\mathrm{MgCO}_{3} \\
(\mathrm{~mol} \%)\end{array}$ & $\begin{array}{l}\mathrm{CaCO}_{3} \\
(\mathrm{~mol} \%)\end{array}$ & $\begin{array}{l}\mathrm{MnCO}_{3} \\
(\mathrm{~mol} \%)\end{array}$ \\
\hline G3 & $1 \mathrm{a}$ & 8.97 & 15.17 & 75.36 \\
\hline G3 & $1 \mathrm{a}$ & 7.89 & 13.07 & 78.47 \\
\hline G3 & $1 \mathrm{a}$ & 9.12 & 20.87 & 69.72 \\
\hline G3 & $1 \mathrm{a}$ & 9.33 & 20.94 & 69.36 \\
\hline G3 & $1 \mathrm{a}$ & 8.97 & 16.55 & 74.01 \\
\hline G3 & $1 \mathrm{a}$ & 9.20 & 22.34 & 68.02 \\
\hline G3 & $1 \mathrm{a}$ & 6.35 & 19.51 & 73.69 \\
\hline G3 & $1 \mathrm{a}$ & 6.44 & 20.29 & 72.92 \\
\hline G3 & $1 \mathrm{a}$ & 7.47 & 20.28 & 71.88 \\
\hline G3 & $1 \mathrm{a}$ & 6.92 & 18.78 & 73.90 \\
\hline G3 & $1 \mathrm{a}$ & 6.44 & 19.42 & 73.70 \\
\hline G3 & $1 \mathrm{a}$ & 7.57 & 19.85 & 72.03 \\
\hline G3 & $1 \mathrm{a}$ & 7.49 & 12.06 & 79.68 \\
\hline G3 & $1 \mathrm{a}$ & 7.32 & 10.43 & 81.66 \\
\hline G3 & $1 \mathrm{a}$ & 9.22 & 22.62 & 67.84 \\
\hline G3 & $2 b$ & 8.67 & 17.20 & 73.55 \\
\hline G3 & $2 b$ & 8.28 & 18.90 & 72.45 \\
\hline G3 & $2 b$ & 7.88 & 21.95 & 69.90 \\
\hline G3 & $2 b$ & 7.44 & 21.38 & 70.83 \\
\hline G3 & $2 b$ & 7.52 & 21.19 & 70.96 \\
\hline G3 & $2 b$ & 7.17 & 21.15 & 71.35 \\
\hline G3 & $2 b$ & 8.27 & 22.67 & 68.70 \\
\hline G3 & $2 b$ & 8.13 & 23.31 & 68.19 \\
\hline G3 & $2 b$ & 8.00 & 23.65 & 68.11 \\
\hline G3 & $2 b$ & 7.93 & 24.15 & 67.48 \\
\hline G3 & $2 b$ & 7.59 & 22.88 & 68.91 \\
\hline G3 & $2 b$ & 7.95 & 23.60 & 68.16 \\
\hline G3 & $2 b$ & 7.87 & 21.84 & 69.81 \\
\hline G3 & $2 b$ & 7.31 & 20.54 & 71.88 \\
\hline G3 & $2 b$ & 7.11 & 19.99 & 72.52 \\
\hline G3 & $2 b$ & 7.73 & 21.30 & 70.59 \\
\hline G3 & $2 b$ & 6.95 & 21.40 & 71.38 \\
\hline G3 & $2 b$ & 7.90 & 22.05 & 69.65 \\
\hline G3 & $2 b$ & 7.67 & 21.31 & 70.60 \\
\hline G3 & $2 b$ & 7.38 & 21.90 & 70.41 \\
\hline G3 & $2 b$ & 9.11 & 22.33 & 65.75 \\
\hline G3 & $2 b$ & 8.23 & 23.68 & 67.75 \\
\hline G3 & $2 b$ & 7.04 & 21.34 & 71.32 \\
\hline G3 & $2 b$ & 6.71 & 20.75 & 72.16 \\
\hline G3 & $2 b$ & 9.60 & 23.62 & 66.57 \\
\hline G3 & $2 b$ & 8.33 & 23.53 & 67.16 \\
\hline G3 & $2 b$ & 8.56 & 22.39 & 68.59 \\
\hline G3 & $2 b$ & 7.96 & 22.84 & 68.83 \\
\hline G3 & $2 b$ & 7.88 & 23.07 & 68.55 \\
\hline G3 & $2 b$ & 7.64 & 22.41 & 69.55 \\
\hline G3 & $2 b$ & 7.86 & 22.10 & 69.29 \\
\hline G3 & $2 b$ & 6.93 & 21.24 & 71.02 \\
\hline G3 & $2 b$ & 6.93 & 21.33 & 70.79 \\
\hline G3 & $2 b$ & 6.77 & 20.14 & 72.18 \\
\hline G3 & $2 b$ & 6.97 & 21.05 & 71.16 \\
\hline G3 & $2 b$ & 7.24 & 20.03 & 71.69 \\
\hline G3 & $2 b$ & 6.91 & 20.73 & 71.95 \\
\hline G3 & $2 b$ & 6.99 & 19.63 & 72.65 \\
\hline G3 & $2 b$ & 7.00 & 19.86 & 72.60 \\
\hline G3 & $2 b$ & 7.42 & 21.05 & 71.08 \\
\hline G3 & $2 b$ & 6.13 & 22.19 & 71.32 \\
\hline G3 & $2 b$ & 8.23 & 22.83 & 67.36 \\
\hline G3 & $2 b$ & 9.22 & 20.43 & 69.89 \\
\hline G3 & $2 b$ & 9.66 & 21.70 & 68.18 \\
\hline G3 & $2 b$ & 8.92 & 23.35 & 67.45 \\
\hline G3 & $2 b$ & 8.89 & 15.51 & 75.01 \\
\hline G3 & $3 a$ & 8.81 & 23.42 & 67.29 \\
\hline G3 & $3 a$ & 9.29 & 22.33 & 68.00 \\
\hline G3 & $3 a$ & 9.07 & 17.63 & 72.84 \\
\hline G3 & $3 a$ & 9.35 & 20.15 & 70.09 \\
\hline G3 & $3 a$ & 8.06 & 22.07 & 69.48 \\
\hline G3 & $3 a$ & 9.56 & 20.84 & 69.43 \\
\hline G3 & $3 a$ & 8.70 & 15.61 & 75.20 \\
\hline G3 & $3 a$ & 9.67 & 21.70 & 68.26 \\
\hline G3 & $3 a$ & 8.51 & 13.48 & 77.48 \\
\hline G3 & $3 a$ & 9.24 & 23.13 & 67.28 \\
\hline G3 & $3 a$ & 9.17 & 24.67 & 65.75 \\
\hline G3 & $3 a$ & 9.35 & 23.81 & 66.36 \\
\hline G3 & $3 a$ & 8.31 & 23.31 & 67.86 \\
\hline G3 & $3 a$ & 8.52 & 13.54 & 77.36 \\
\hline G3 & $3 a$ & 9.10 & 17.39 & 72.94 \\
\hline G3 & $3 a$ & 9.41 & 17.61 & 72.63 \\
\hline G3 & $3 a$ & 8.94 & 24.64 & 66.06 \\
\hline G3 & $3 a$ & 8.82 & 19.98 & 70.25 \\
\hline G3 & $3 a$ & 8.14 & 22.13 & 69.32 \\
\hline G3 & $3 a$ & 9.13 & 25.28 & 65.44 \\
\hline G3 & $3 a$ & 8.63 & 25.02 & 65.98 \\
\hline G3 & $3 a$ & 8.46 & 23.17 & 68.13 \\
\hline G3 & $3 a$ & 8.69 & 24.57 & 66.47 \\
\hline G3 & $3 a$ & 9.22 & 20.58 & 69.93 \\
\hline G3 & $3 a$ & 8.83 & 16.27 & 74.61 \\
\hline G3 & $3 a$ & 9.16 & 18.73 & 71.85 \\
\hline
\end{tabular}

\begin{tabular}{|c|c|c|c|c|}
\hline Generation & $\begin{array}{c}\text { Sample } \\
\text { 156-948D-no. }\end{array}$ & $\begin{array}{l}\mathrm{MgCO}_{3} \\
(\mathrm{~mol} \%)\end{array}$ & $\begin{array}{l}\mathrm{CaCO}_{3} \\
(\mathrm{~mol} \%)\end{array}$ & $\begin{array}{l}\mathrm{MnCO}_{3} \\
(\mathrm{~mol} \%)\end{array}$ \\
\hline G3 & $3 a$ & 9.20 & 21.07 & 69.37 \\
\hline G3 & $3 a$ & 9.54 & 19.22 & 71.00 \\
\hline G3 & $3 a$ & 7.90 & 23.05 & 68.86 \\
\hline G3 & $3 a$ & 9.00 & 24.79 & 65.87 \\
\hline G3 & $3 a$ & 9.14 & 22.44 & 68.16 \\
\hline G3 & $3 a$ & 9.20 & 22.48 & 68.03 \\
\hline G3 & $3 a$ & 7.89 & 22.64 & 69.05 \\
\hline G3 & $3 a$ & 8.91 & 24.63 & 66.10 \\
\hline G3 & $3 a$ & 9.43 & 24.69 & 65.63 \\
\hline G3 & $3 a$ & 7.90 & 22.93 & 68.75 \\
\hline G3 & $3 a$ & 9.43 & 22.47 & 67.86 \\
\hline G3 & $3 a$ & 8.69 & 16.86 & 74.11 \\
\hline G3 & $5 a$ & 8.36 & 24.26 & 67.06 \\
\hline G3 & $5 a$ & 8.58 & 24.77 & 66.39 \\
\hline G3 & $5 a$ & 8.65 & 25.79 & 65.32 \\
\hline G3 & $5 \mathrm{a}$ & 8.77 & 24.98 & 66.00 \\
\hline G3 & $5 a$ & 8.70 & 26.37 & 64.76 \\
\hline G3 & $5 a$ & 9.49 & 25.94 & 64.40 \\
\hline G3 & $5 \mathrm{a}$ & 9.23 & 25.92 & 64.71 \\
\hline G3 & $5 a$ & 8.80 & 24.78 & 65.42 \\
\hline G3 & $5 a$ & 8.96 & 19.98 & 70.48 \\
\hline G3 & $5 a$ & 6.47 & 22.08 & 71.15 \\
\hline G3 & $5 a$ & 7.76 & 22.11 & 69.80 \\
\hline G3 & $5 a$ & 8.50 & 25.29 & 65.93 \\
\hline G3 & $5 a$ & 9.41 & 24.50 & 65.71 \\
\hline G3 & $5 a$ & 7.59 & 22.70 & 69.38 \\
\hline G3 & $5 a$ & 7.26 & 20.70 & 71.69 \\
\hline G3 & $5 a$ & 6.85 & 22.06 & 70.80 \\
\hline G3 & $5 a$ & 6.94 & 21.35 & 71.31 \\
\hline G3 & $5 a$ & 5.98 & 22.42 & 71.36 \\
\hline G3 & $5 a$ & 7.04 & 21.10 & 71.47 \\
\hline G3 & $5 a$ & 6.68 & 20.54 & 72.45 \\
\hline G3 & $5 a$ & 8.35 & 21.23 & 70.12 \\
\hline G3 & $5 a$ & 9.27 & 21.78 & 68.67 \\
\hline G3 & $5 a$ & 8.13 & 23.38 & 68.21 \\
\hline G3 & $5 \mathrm{a}$ & 9.07 & 25.67 & 65.09 \\
\hline G3 & $5 a$ & 9.15 & 25.39 & 65.28 \\
\hline G3 & $5 a$ & 9.19 & 20.43 & 70.26 \\
\hline G3 & $5 \mathrm{a}$ & 8.72 & 25.90 & 65.16 \\
\hline G3 & $5 \mathrm{a}$ & 8.69 & 12.93 & 77.94 \\
\hline G3 & $5 a$ & 9.29 & 24.66 & 65.77 \\
\hline G3 & $5 a$ & 8.34 & 24.20 & 67.05 \\
\hline G3 & $5 a$ & 8.54 & 23.88 & 67.35 \\
\hline G3 & $5 a$ & 8.40 & 23.13 & 68.06 \\
\hline G3 & $5 \mathrm{a}$ & 8.37 & 25.43 & 65.96 \\
\hline G3 & $5 \mathrm{a}$ & 9.26 & 24.98 & 65.54 \\
\hline G3 & $5 a$ & 9.26 & 22.98 & 67.48 \\
\hline G3 & $5 a$ & 8.65 & 24.86 & 66.06 \\
\hline G3 & $5 a$ & 9.23 & 21.77 & 68.61 \\
\hline G3 & $5 a$ & 9.20 & 25.24 & 65.23 \\
\hline G3 & $5 a$ & 6.02 & 22.71 & 70.84 \\
\hline G3 & $5 \mathrm{a}$ & 6.64 & 23.56 & 69.59 \\
\hline G3 & $5 a$ & 6.69 & 21.85 & 71.13 \\
\hline G3 & $5 a$ & 8.41 & 23.58 & 67.62 \\
\hline G3 & $5 \mathrm{a}$ & 9.20 & 25.50 & 64.95 \\
\hline G3 & $5 a$ & 9.24 & 25.66 & 64.92 \\
\hline G3 & $5 a$ & 9.58 & 24.62 & 65.48 \\
\hline G3 & $5 a$ & 9.59 & 26.04 & 64.03 \\
\hline G3 & $5 \mathrm{a}$ & 9.20 & 24.70 & 65.72 \\
\hline G3 & $5 a$ & 9.09 & 25.74 & 64.93 \\
\hline G4 & $1 \mathrm{a}$ & 2.36 & 65.17 & 32.36 \\
\hline G4 & 1a & 2.47 & 64.65 & 32.65 \\
\hline G4 & 1a & 2.41 & 67.68 & 29.79 \\
\hline G4 & $2 b$ & 2.17 & 67.64 & 30.06 \\
\hline G4 & $2 b$ & 2.15 & 69.44 & 28.26 \\
\hline G4 & $2 b$ & 2.23 & 67.20 & 30.29 \\
\hline G4 & $2 b$ & 2.21 & 68.22 & 29.43 \\
\hline G4 & $5 a$ & 2.68 & 70.68 & 26.52 \\
\hline G4 & $5 a$ & 2.69 & 71.42 & 25.66 \\
\hline G4 & $5 \mathrm{a}$ & 2.75 & 70.63 & 26.36 \\
\hline G4 & $5 a$ & 2.74 & 72.00 & 25.17 \\
\hline G4 & $5 \mathrm{a}$ & 2.78 & 70.68 & 26.21 \\
\hline G4 & $5 \mathrm{a}$ & 2.22 & 70.34 & 27.27 \\
\hline G4 & $5 \mathrm{a}$ & 2.18 & 69.15 & 28.57 \\
\hline G4 & $5 a$ & 1.68 & 76.28 & 21.93 \\
\hline G4 & $5 \mathrm{a}$ & 2.03 & 70.69 & 27.16 \\
\hline G4 & $5 \mathrm{a}$ & 2.01 & 68.77 & 29.16 \\
\hline G4 & $5 a$ & 1.74 & 73.54 & 24.58 \\
\hline G4 & $5 \mathrm{a}$ & 1.89 & 71.08 & 26.89 \\
\hline G4 & $5 \mathrm{a}$ & 1.89 & 69.56 & 28.49 \\
\hline G4 & $5 a$ & 2.07 & 68.44 & 29.36 \\
\hline G4 & $5 a$ & 2.29 & 67.13 & 30.50 \\
\hline G4 & $5 a$ & 2.53 & 66.32 & 31.00 \\
\hline
\end{tabular}

Notes: Analysis points are grouped according to the different generations of carbonate precipitates. Results are expressed in mole percent $(\mathrm{mol} \%)$ carbonate. 
Table 3. Summary of mean, median, maximum, and minimum values of magnesium, calcium, and manganese carbonate in the different generations of Type 4 vein-fills, Hole 948D.

\begin{tabular}{|c|c|c|c|c|}
\hline Generation & Value & $\begin{array}{l}\mathrm{MgCO}_{3} \\
(\mathrm{~mol} \%)\end{array}$ & $\begin{array}{l}\mathrm{CaCO}_{3} \\
(\mathrm{~mol} \%)\end{array}$ & $\begin{array}{l}\mathrm{MnCO}_{3} \\
(\mathrm{~mol} \%)\end{array}$ \\
\hline G1 & Mean & 7.42 & 9.80 & 82.31 \\
\hline G1 & Median & 7.37 & 9.70 & 82.71 \\
\hline G1 & Maximum & 9.10 & 13.45 & 87.29 \\
\hline G1 & Minimum & 6.41 & 5.97 & 77.98 \\
\hline $\mathrm{Gl}^{\prime}$, & Mean & 7.97 & 12.76 & 78.89 \\
\hline $\mathrm{G} 1^{\prime}$ & Median & 7.89 & 12.28 & 79.99 \\
\hline $\mathrm{Gl}^{\prime}$ & Maximum & 9.24 & 23.18 & 86.62 \\
\hline $\mathrm{G} 1^{\prime}$ & Minimum & 6.81 & 5.99 & 68.34 \\
\hline $\mathrm{G} 2$ & Mean & 7.43 & 9.32 & 82.84 \\
\hline $\mathrm{G} 2$ & Median & 7.42 & 9.12 & 82.44 \\
\hline G2 & Maximum & 8.86 & 13.94 & 87.77 \\
\hline G2 & Minimum & 6.35 & 5.43 & 76.75 \\
\hline $\mathrm{G} 2^{\prime}$ & Mean & 8.41 & 13.94 & 77.29 \\
\hline $\mathrm{G} 2^{\prime}$ & Median & 8.52 & 13.47 & 77.66 \\
\hline $\mathrm{G} 2^{\prime}$ & Maximum & 9.55 & 23.11 & 83.95 \\
\hline $\mathrm{G} 2^{\prime}$ & Minimum & 7.15 & 8.13 & 67.00 \\
\hline G3 & Mean & 8.35 & 21.34 & 70.50 \\
\hline G3 & Median & 8.50 & 21.90 & 69.65 \\
\hline G3 & Maximum & 9.67 & 26.37 & 81.66 \\
\hline G3 & Minimum & 5.98 & 9.69 & 64.03 \\
\hline G4 & Mean & 2.27 & 69.42 & 28.16 \\
\hline G4 & Median & 2.22 & 69.44 & 28.49 \\
\hline G4 & Maximum & 2.78 & 76.28 & 32.65 \\
\hline G4 & Minimum & 1.68 & 64.65 & 21.93 \\
\hline
\end{tabular}

Note: Calculated from results presented in Table 2.

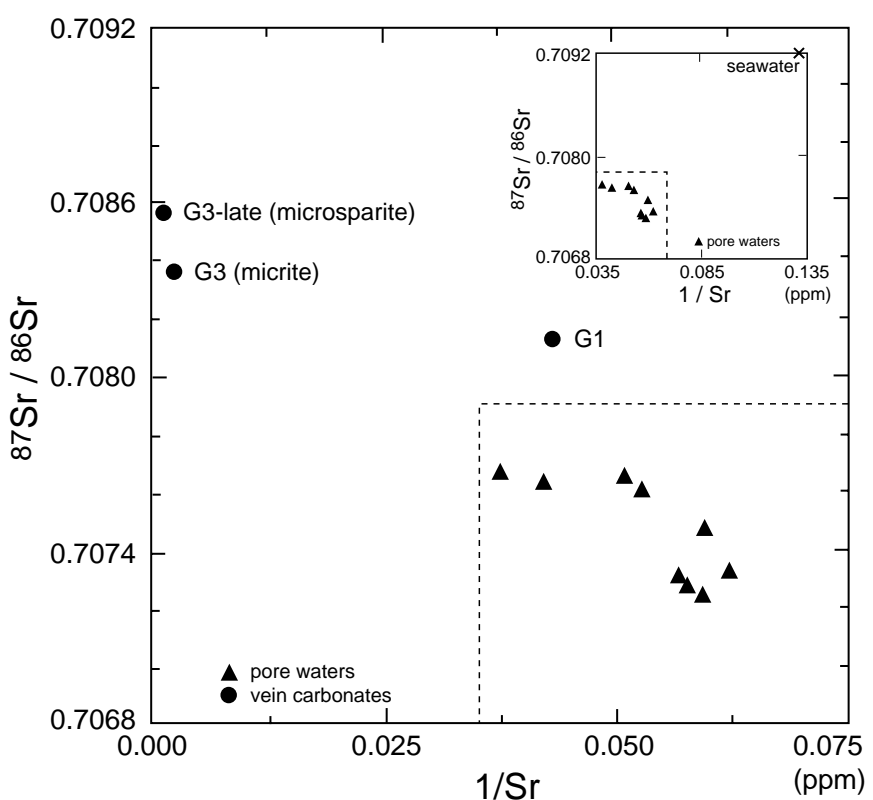

Figure 14. Mixing relationships between ${ }^{87} \mathrm{Sr} /{ }^{86} \mathrm{Sr}$ ratios and $1 / \mathrm{Sr}$ concentrations (in ppm) of the pore waters and carbonates in Type 4 veins at Site 948. Pore waters were sampled in Hole 948C and the carbonate veins were recovered at neighboring Hole 948D. G1 and G3: first and third generations of vein carbonates. The dashed line delineates the area with the pore-water data. The small diagram at top right shows the difference between pore waters and contemporaneous seawater values.
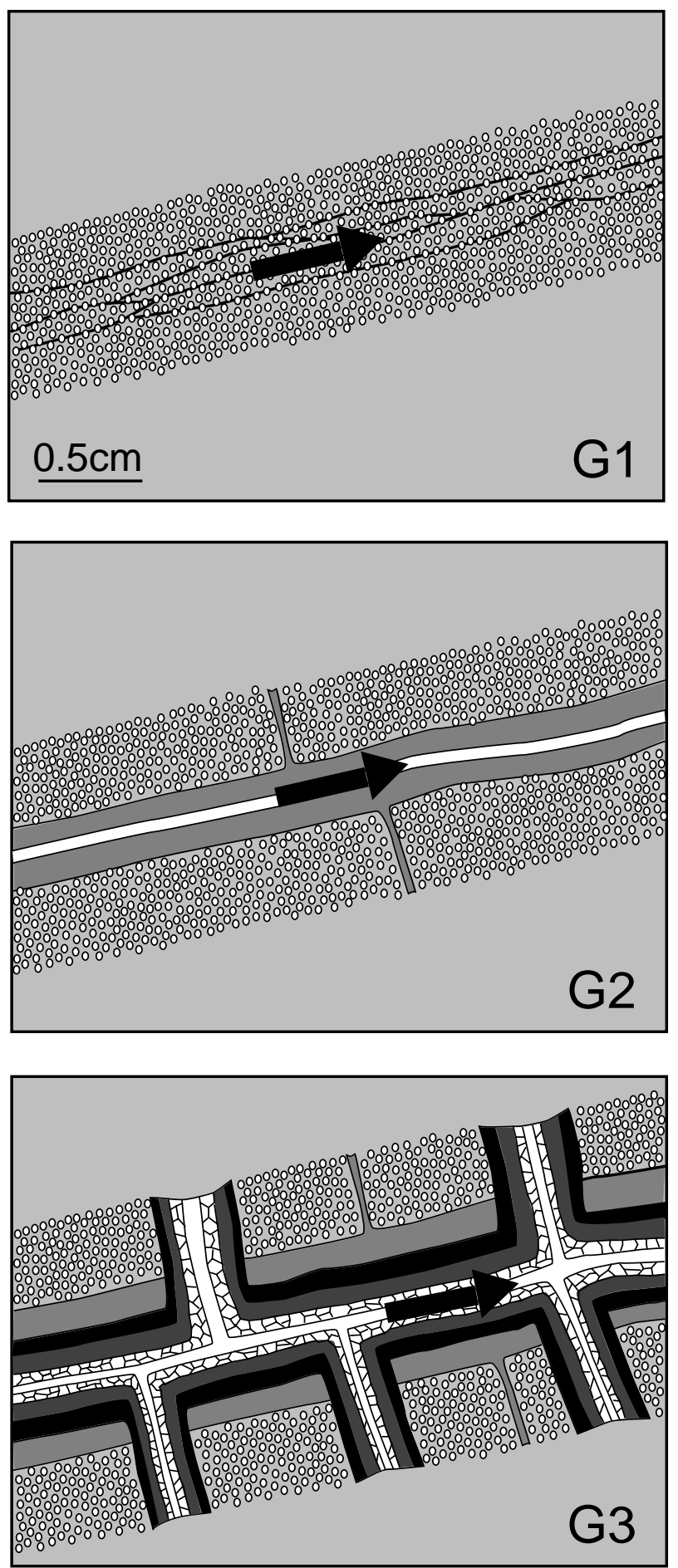

Figure 15. Sketch of Type 4 vein evolution. G1, G2, and G3 are successive vein-carbonate generations ( $\mathrm{G} 4$ is not shown, and the vein external geometry is hypothetical). Light gray = clayey host-sediment, medium gray and black = micrite, decorated white $=$ microsparite, arrows $=$ fluid flow in fractures. In G1, the fluid circulates in narrow fractures and percolates in the surrounding matrix porosity where carbonate crystal nucleation occurs at sites dispersed in the clayey sediment, resulting in an agglomerate of poorly connected spheroidal crystals and abundant clayey inclusions. In G2 and G3, the fluid circulates in open channels (white), resulting in precipitation of micrite, followed by late-microsparite. Both G2 and G3 comprise a great number of successive episodes of rupture and precipitation (crack sealing). Solid inclusions are still present during the initial stages of G2, then disappear. Crystal size in G1 and the late microsparite in $\mathrm{G} 3$ is exaggerated. 

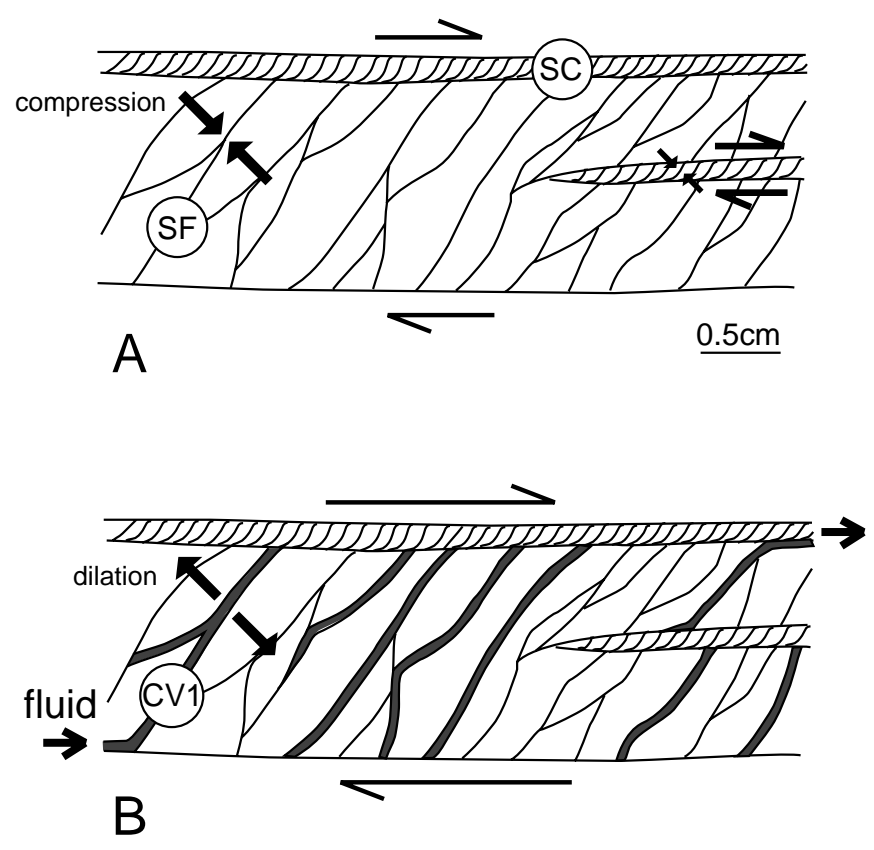

Figure 16. Relationships between formation of scaly fabrics and formation of Type 1 carbonate veins in scaly-fabric zones (shear zones). A. Formation of deformation bands referred to as SC bands (SC), and spaced foliation (SF; see Labaume et al., Chapter 4, this volume) caused by compactional plastic strain (pore collapse) during stages of relatively low pore pressure. B. Dilation of deformation bands and precipitation of carbonate veins (CV1) by circulating fluid during stages of overpressured fluid injection. During the latter stages, compactional strain (pore collapse) is inhibited by high pore pressure, but displacement at the shear-zone boundaries is likely to be facilitated. 